\title{
The Role of Remittances on Financial Development through Capital Formation and FDI Channels: A Symmetric and Asymmetric Investigation for Selected South Asian Countries
}

\author{
Md. Qamruzzaman,", ${ }^{1,}$ Rajnish Kler² \\ ${ }^{1}$ School of Business and Economics, United International University, Dhaka, Bangladesh \\ ORCID: https://orcid.org/0000-0002-0854-2600 \\ ${ }^{2}$ Department of Commerce, Motilal Nehru College (E), University of Delhi, Delhi-11002, India
}

Received August 31, 2021; Revised November 2, 2021; Accepted November 21, 2021

\section{Cite This Paper in the following Citation Styles}

(a): [1] Md. Qamruzzaman, Rajnish Kler, "The Role of Remittances on Financial Development through Capital Formation and FDI Channels: A Symmetric and Asymmetric Investigation for Selected South Asian Countries," Universal Journal of Accounting and Finance, Vol. 9, No. 6, pp. 1433-1453, 2021. DOI: 10.13189/ujaf.2021.090621.

(b): Md. Qamruzzaman, Rajnish Kler (2021). The Role of Remittances on Financial Development through Capital Formation and FDI Channels: A Symmetric and Asymmetric Investigation for Selected South Asian Countries. Universal Journal of Accounting and Finance, 9(6), 1433-1453. DOI: 10.13189/ujaf.2021.090621.

Copyright $\odot 2021$ by authors, all rights reserved. Authors agree that this article remains permanently open access under the terms of the Creative Commons Attribution License 4.0 International License

\begin{abstract}
The motivation of the study is to gauge the asymmetric effects of remittances (R), gross capital formation (GCF), and FDI on financial development (FD) in Bangladesh, India, Pakistan, and Srilanka spanning the period 1978-2018. The study applied unit root tests, including DF-GLS and Zivot-Andrew, ARDL bound test, tBDM test, Bayer and Hanck combined cointegration test, nonlinear ARDL (NARDL) for asymmetry, and, finally, directional causal effects evaluated with the Toda-Yamamoto causality test. ARDL bound testing documents the long-run association between R, GCF, FDI, and FD, valid for sample countries. Additionally, remittance elasticity exposes a positive, statistically significant linkage with financial development in the long run and short run. The standard Wald test reveals that the test statistics are statistically significant at $1 \%$ level, suggesting the asymmetric association between financial development and explanatory variables. The asymmetric association is valid both in the long-run and short-run. With the asymmetric effects of remittances, positive and negative shocks expose positive, statistically significant at a $1 \%$ level both in the long-run and short-run. However, in coefficient elasticities, harmful innovations are more critical to financial development than positive innovations
\end{abstract}

in remittances. It suggests that policymakers have to make efforts to formulate policies that induce the migrants to send remittances to the economy. Finally, the directional causality test results disclosed unidirectional causality running from remittances to financial development.

Keywords Remittances, Financial Development, ARDL, NARDL, Toda-Yamamoto Causality

\section{Introduction}

Over the last few decades, remittances have emerged as important sources of economic growth, alleviating poverty and inequality, fostering vibrant financial development and inclusion, accumulating domestic capital creation, and expanding trade, particularly in emerging countries. Financial development is a critical area where the importance of remittances has been recognized. The researchers sought to gain a new understanding by concentrating on the nexus between remittance-driven economic trends. However, any definitive conclusion about the effect of remittances has yet to be established 
since it is dependent on the condition of the economy and the kind of econometric analysis used. Given the available empirical evidence, it is clear that a variety of factors contribute to financial development. For example, institutional quality, geographic characteristics, macroeconomic policies, income level, and cultural characteristics all have a positive effect on the level of financial development [1]. Political power is a significant determinant of economic institutions, which affects the development of financial institutions [2]. Financial growth is influenced by the adaptability and flexibility of legal systems. Additionally, high settler death rates during the early phases of colonization have harmed present levels of financial growth [3].

International remittances are critical to South Asia's economic growth, with most inflows coming from Gulf nations. The latter economies have been severely affected by the Covid-19 epidemic, but this has had little effect on the increasing quantities of hard cash returned home by most South Asian nations. In certain cases, communities affected by a crisis gain from an increase in remittances. For example, Nepal saw a large rise in remittance inflows after the 2015 earthquake, while a flooding catastrophe in India's southern state of Kerala is believed to have increased remittances to India in 2018 [4]. Between 2015 and 2019, a little more than one-fifth of worldwide remittances were sent to South Asian nations - with India, the biggest beneficiary, getting close to USD 360 billion over the time. Nepal has the biggest remittance inflow in the region as a percentage of GDP and the fifth-largest globally (1/3 of GDP between 2015 and 2019). Sri Lanka (8.3 percent of GDP), Pakistan (7.1\%), and Bangladesh (6.2 percent) are next, followed by India (2.9 percent), Bhutan (1.8 percent), and the Maldives ( 0.1 percent). In Bhutan and the Maldives, inflows are typically less than outflows, with net remittances totaling -0.6 percent and -9.5 percent of GDP, respectively, from 2015 to 2019[5]. Over the past decades, remittances have emerged as critical sources of economic progress by mitigating poverty, inequality, thriving financial development, financial inclusion, accumulation of domestic capital formation, and trade expansion, especially in developing economies. Financial development is the key area where the contribution of remittances has been significantly acknowledged. Researchers tried to explore fresh insight, focusing nexus between remittances-led financial developments. However, any conclusive statement yet to establish due to remittances' impact varies with the state of the economy and the application of econometrical assessment.

The motivation of this study is to gauge the impact of remittances on financial development through the channel of gross capital formation and attracting FDI in selected South Asian countries (Bangladesh, India, Pakistan, and Srilanka) for the period 1978-2018. The study applied several econometrical toots for detecting association in empirical assessment. DF-GLS and Zivot-Andrew ascertain variables stationary properties and documents. All the variables are stationary either at a level or after first difference but neither after second difference. For detecting long-run association, the study utilized the combined cointegration test proposed by Bayer and Hanck [6], Fpass bound testing following Pesaran, Shin [7], Wpass with Joint probability test, and tBDM test following Banerjee, Dolado [8]. Considering the test statistics, it is apparent that all the test statistics are statistically significant at a $1 \%$ level, implying the rejection of "no-cointegration". Alternatively, test statistics ascertain the long-run association between remittances gross capital formation, FDI, and financial development, which refers to the long-run coefficient of remittance, gross capital formation, and FDI document positive statistically significant association with the measures of financial development. Furthermore, the interactive term for assessing the mediating role of remittance through capital formation reveals positive and statistically significant, implying that remittance enhances financial development by accelerating the capital accumulation process in the economy. The asymmetric investigation with nonlinear farm work following Shin, $\mathrm{Yu}$ [9] disclosed the asymmetric relationship between remittances, gross capital formation, FDI, and financial development. The standard Wald test confirms the asymmetry effects running from R GCF and FDI to FD in the long and short run. The directional causality test reveals the evidence favoring the feedback hypothesis for bidirectional causality to explain the causality between financial development and remittances $[\mathrm{FD} \leftarrow \rightarrow \mathrm{R}]$ in all four countries assessment. The findings supported by the exiting literature can be seen in [10-12]. Even though remittances are the source of financial sector growth, more extraordinary records of remittances may be accounted for since better financial development leads to higher measures of money sent via formal channels [13].

The remaining structure of the paper is as follows. Section II deals with the literature survey and the study's variable definition and methodology explained in Section III. Empirical model estimation and interpretation are available in Section IV, and finally, summary findings display in Section V.

\section{Review of the Literature}

\section{Remittance-led financial development}

Remittances have a variety of consequences for the financial industry. First and foremost, the transaction fee on remittances is a major source of revenue for commercial banks, which is one of the primary reasons for establishing branches in rural areas (for locating close to remittance recipients). Secondly, migrant families have been sitting on a large amount of cash for some time. 
They need banking services for main deposits because banks provide those families with a secure location to store their temporary surplus cash. To add to this, many remittances are sent to families who are likely not to have bank accounts; as a result, banks that serve as remittance payment agents have a strong organizational structure and are in a position to provide additional services unbanked homes that receive remittances. Fourth, the deposits made by migrant families may help financial institutions decrease their reliance on external funding. As a consequence, obtaining a loan for the average person in underdeveloped nations may become less difficult. Fifth, via the processing of remittances flows, banks may get information on the income of recipient families. Banks may be better equipped to offer loans to borrowers who are otherwise difficult to identify due to this information.

There is a substantial body of research on the impact of remittances on different aspects of socioeconomic growth. It addresses economic growth, household savings, small company investment, health and education, poverty, and inequality[14-16]. Several cross-country studies have examined the impact of remittances on growth while considering the banking sector's expansion [17]. Finance has a significant influence on remittances. Additionally, they discover that remittances boost growth in the absence of financial development. Abdih, Chami [18] establish the stabilizing impact on production, whereas [19] reports a substantial influence on growth for nations with higher financial development. Ringel, Schlomann [20] reviewed the growth-remittances connection, emphasizing that cross-country research may reveal results with measurement problems and poor explanatory power.

Shanthi, Sircar [21] investigated the impact of remittance inflows on banking sector growth in Sub-Saharan African nations between 1994 and 2009 using fixed effects and random effects. The study's results showed that remittance inflows have a substantial impact on the growth of the banking system in selected nations. Demirguc-Kunt and Peria [13] conducted another research utilizing household survey data from 2000 using multiple regression. According to results of the study, remittances are significantly linked with increased banking breadth and depth, as measured by the number of branches and accounts per capita and deposits as a percentage of GDP. Aggarwal, Demirguc-Kunt [22] examine the effect of remittances on the growth of the banking industry. Their empirical research shows a positive and healthy effect of remittances on financial sector growth, even after accounting for other variables affecting financial development and adjusting for several possible sources of bias in our findings.

Financial systems are often defined by their capacity to generate ex-ante knowledge about potential investments, monitor them, mobilize and pool resources, and distribute money. After supplying financing, the dynamics exercise corporate governance by facilitating trade, risk diversification, risk management, and facilitating the exchange of commodities and services [23]. Additionally, offering financial services to people will increase savings and beneficial investments[24]. Financial liberalization and market efficiency need robust institutional frameworks, such as legal infrastructure, bankruptcy laws, transparency standards, and prudential regulators. In general, financial sector reform is required to enhance remittance policies via 'banking the unbanked.

In another research, Raza, Jawaid [25] used ARDL bound testing in Pakistan from 1976 to 2011. The study showed that foreign direct investment, worker remittances, and economic growth substantially are positively associated with a stock market capitalization in the long and short term. Nonetheless, there is a one-way causal connection between worker remittances and stock market capitalization. It is suggested that an investor in Pakistan may make investment choices by keeping a watch on the direction of the regarded foreign capital inflows and economic development. Furthermore, El-Nader and Alraimony [26] used Unit Root Tests in Jordan from 1990 to 2011. According to the research results, the money supply concerning GDP, total value exchanged concerning GDP, gross capital creation concerning GDP, consumer price index, and credit to the private sector about GDP all positively and significantly affect stock-market growth.

On the other hand, nominal GDP and net remittances linked with GDP have hampered stock market growth. Billmeier and Massa [27] used fixed effects to examine 17 countries in the Middle East and Central Asia from 1995 to 2005. According to the study, remittances and institutions have a favorable and substantial effect on market capitalization. The oil price drives stock market capitalization in resource-rich nations.

The research does not completely establish the connection between financial development and remittances.

According to Ngare, Nyamongo [28] and Aggarwal, Demirgüç-Kunt [29], formal remittance routes promote financial sector development. This uncertainty is exacerbated when beneficiaries establish accounts with commercial banks. Remittances positively impact banking by requiring receivers to deposit money in banks for safe keeping and by requiring recipients to seek additional bank goods or services. Credit outstanding may also arise as a result of remittances since banks may loosen credit restrictions on remittance receivers in accordance with the 'induced financial literacy' concept. On the other side, remittances may help decrease credit demand by relieving families of their financial restrictions [17]. As a result, remittances may serve as a source of credit outside of established financial channels, promoting nonbank activities.

\section{Remittances and Capital formation}

In developing nations, remittances are rapidly 
becoming significant sources of income and, possibly, investment capital. For governments in developing countries, remittances represent a reliable source of foreign funding. One of the routes via which remittances are anticipated to affect long-run economic development is domestic capital creation, which may be influenced by various factors such as an induced increase in savings and the alleviation of financial restrictions [30]. Remittances are expanding throughout countries, and some experts believe that sending money back home might be used as a source of capital to accomplish development goals. Migrant remittances are a portion of the salaries, along with compensation, that international migrant workers send back to their home countries (home country)[31]

Financial sector growth lags in many impoverished countries, in which case remittances alleviate credit and liquidity restrictions. Additionally, the influence of remittances on the economic health of the sending country is said to be heavily reliant on the degree of financial development in the sending country. The overall economic situation will improve as a more developed financial sector would redirect more funds to invest [32]. In a study Ratha [33] evaluate the role of remittances in external financing development in the economy and documents the positive impact. He advocates that excess money flows in the financial system in foreign remittances allure households for a higher degree of consumption and saving propensity for the future. The accumulative effects of society saving inclination support domestic capital aggregation. Countries may boost remittance flows by improving the infrastructure of the banking sector and making foreign travel more convenient, thus bringing more money into the formal financial system[17, 34].

However, the expected effects of remittance on capital accumulation through domestic investment shall not produce the usual output all the time. Having remittances recipient higher degree of consumption propensity diminishes the scope of fund accumulation by enjoying savings opportunity in society. [35]. Remittances may also have additional macroeconomic consequences, which may have the effect of discouraging investment activity. Higher inflation and genuine exchange rate appreciation result from an induced increase in foreign reserves and money supply (in a fixed exchange rate regime) and an appreciation of the nominal exchange rate in a flexible exchange rate regime [36-38]. Remittances may contribute to inflation since they boost demand for consumer goods and services, primarily when the economy cannot satisfy the additional demand [39]. These would create an unfavourable environment for economic activity, which would, in turn, discourage investment. Similarly, genuine appreciation as a consequence of increasing financial inflows would, all else being equal, reduces the competitiveness of locally produced traded products, with the potential of reducing capital creation in the economy.

\section{Foreign direct investment and financial development}

In the context of FDI, host economies are likely to profit due to knowledge spillovers brought about by the technology and know-how embedded in these investments. Spillovers can be initiated through a variety of channels, such as transfers of technological capabilities, the introduction of new production and processing methods, and the distribution of managerial and expertise capabilities to the country's domestic market, where additional productivity gains can be realized through backward and forward linkages between foreign and domestic firms. FDI can also help increase capital accumulation, which accompanies these technological breakthroughs. Foreign capital flowing into the host economy could potentially contribute to the growth of physical capital, while training for the workforce may foster skills. Investing in foreign direct investment (FDI) is widely recognized as a reliable source of money for developing economies. FDI is often an essential strategy for accomplishing economic growth and development. A majority of research on FDI is concerned with whether there is a correlation between FDI and economic growth or whether there is a correlation between FD and economic growth. Foreign direct investment (FDI) is associated with an improvement in developing a country's financial markets.

The first line of thought suggests the positive association between FDI inflows and financial development [40-47]. When foreign direct investment net inflows grow, the nation's economic activities benefit as more money is made accessible to the economy due to this increase[48]. As a result, financial intermediation via readily accessible financial markets or the banking system would be improved[49]. Foreign investors are drawn to well-functioning financial markets because they indicate openness from governments, a symbol of energy, and a market-friendly atmosphere, all of which encourage them to make further investments in the country. Asamoah and Alagidede [50] gauge the impact of FDI on financial development by employing two-step GMM over the period 1990-2017 by taking sectoral inflows of FDI. Study findings reveal financial institutional development exposes a positive statistically significant association with FDI but no effects on institutions based on agriculture. Soumaré and Tchana Tchana [51]use the granger causality test for detecting causal effects retuning between FDI and financial development with a panel of 29 emerging countries. Study unveils feedback hypothesis prevail in to explain the causality between FDI and financial development.

The second line of the literature suggests that excessive inflows of FDI play a detrimental role in financial development [47, 52, 53]. Excessive inflows of FDI in the economy entice a higher degree of corruption - such as excessive patronage, nepotism, employment reservations, favoritism, hidden party financing, and suspiciously tight 
connections between politicians and business-is shown in emerging nations that suffer a more considerable amount of corruption. However, no effect is find in literature for instance, Abidin, Haseeb [54];

\section{Conceptual framework and proposed hypothesis of the study}

In literature, several studies have been imitated to gauge the determinants of financial development by taking either panel or time-series data. The underlying motivation of the study is not to explore the critical macro determinants for financial development for the south Asian economy instead of identifying the possible association between remittance, foreign direct investment, gross capital formation and financial development. The following conceptual model is to be implemented in empirical model estimation and unleashes the available causal effects.

$\mathrm{H}^{1}$ : $\mathrm{AB}$ : Financial development granger causes Remittances and vice-versa

$\mathrm{H}^{2}$ : AB: Financial development granger causes the gross capital formation and vice-versa

$\mathrm{H}^{3}$ : $\mathrm{AB}$ : Gross Capital formation granger causes FDI and vise-versa

$\mathrm{H}^{4}$ : $\mathrm{AB}$ : Remittances granger causes FDI and vise-versa

$\mathrm{H}^{5}$ : $\mathrm{AB}$ : remittances granger causes the gross capital formation and vice-versa

H6: AB: Financial development granger causes FDI and vise-versa

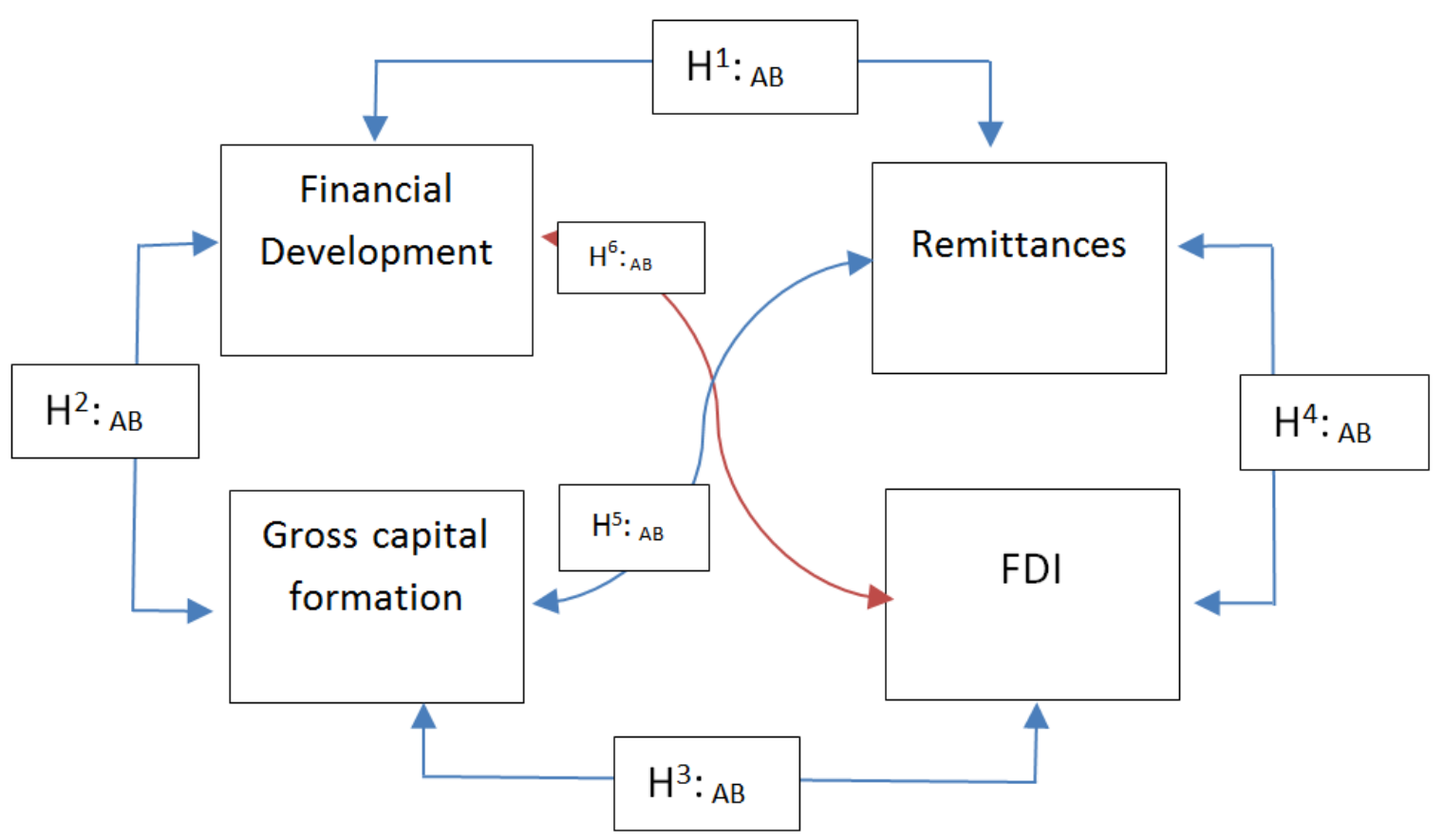




\section{Data and Methodology of the Study}

This study uses annual time series data spanning from 1978-2018. All the data were extracted from World economic Indicators published by World Bank and international financial statistics published by International Monetary Fund (IMF). All the variables are transformed into a natural logarithm before estimation. The dependent variable financial development is measured by considering the financial development index, constructed by applying Principal Component Analysis. Remittances are measured by remittances received as a \% of GDP.

Financial development refers to the factors, policies, and institutions that lead to effective financial intermediation and markets, and deep and broad access to capital and financial services" (Financial Development Index, 2008). Levine [55] underpinned the importance of financial development in promoting economic growth. The theory suggests that remittances can lead to banking system development because money transferred through the banking system paves the way for the recipient to gain access to banking products and services, thereby increasing demand [56]. In the empirical study, several proxies were used. However, in the study, I prefer developing a financial development index by considering four proxies representing the banking industry and the capital market (see Table 1) because index proxy is capable to produce more efficient estimation than single proxy indicator.

By taking into account the research variables, the generalized conceptual model can be represented in the following generalized empirical model can be expressed;

$$
F D \int R, G C F, F D I
$$

All the variables are transformed into natural logarithm, and the empirical equation for assessing the nexus between remittances, gross capital formation, FDI, and financial development is constructed as follows:

$$
F D_{t}=\beta_{1}+\beta_{2} R_{i}+\beta_{3} G C F_{i}+\beta_{4} T O_{i}+\epsilon_{i}
$$

FD stands for financial development measures by financial development index constructed by considering four indicators with the implementation of PAC, $\mathrm{R}$ denotes for remittances, GCF for gross capital formation, and FDI denotes inflows of foreign direct investment.

The generalized ADRL model for assessing the long-run association between financial development, remittances, gross capital formation and foreign direct investment is as follows where each variable is treated as a dependent variable in the equation.

$$
(1-\mathrm{B})\left[\begin{array}{c}
\ln \mathrm{FD} \\
\ln \mathrm{R} \\
\ln \mathrm{GCF} \\
\ln \mathrm{FDI}
\end{array}\right]_{\mathrm{t}}=\left[\begin{array}{c}
\alpha_{01} \\
\alpha_{02} \\
\alpha_{03} \\
\alpha_{04} \\
\alpha_{05} \\
\alpha_{06}
\end{array}\right]+\sum_{\mathrm{k}=1}^{\mathrm{n}}(1-
$$

в) $\left[\begin{array}{l}\gamma_{11} \gamma_{12} \gamma_{13} \gamma_{14} \\ \gamma_{21} \gamma_{22} \gamma_{23} \gamma_{24} \\ \gamma_{31} \gamma_{32} \gamma_{33} \gamma_{34} \\ \gamma_{41} \gamma_{42} \gamma_{43} \gamma_{44}\end{array}\right] \times\left[\begin{array}{c}\operatorname{lnFD} \\ \ln R \\ \operatorname{lnGCF} \\ \operatorname{lnFDI}\end{array}\right]_{\mathrm{k}-\mathrm{t}}+\left[\begin{array}{c}\delta_{11} \delta_{12} \delta_{13} \delta_{14} \\ \delta_{21} \delta_{22} \delta_{23} \delta_{24} \\ \delta_{31} \delta_{32} \delta_{33} \delta_{34} \\ \delta_{41} \delta_{42} \delta_{43} \delta_{44}\end{array}\right] \times$

$$
\left[\begin{array}{c}
\operatorname{lnFD} \\
\ln \mathrm{R} \\
\operatorname{lnGCF} \\
\ln F D I
\end{array}\right]_{\mathrm{t}-1}+\left[\begin{array}{c}
\varepsilon_{1} \\
\varepsilon_{2} \\
\varepsilon_{3} \\
\varepsilon_{4}
\end{array}\right]_{\mathrm{t}}
$$

Where $\Delta$ indicates differencing of variables, while $\varepsilon_{t}$ is the error term (white noise), and (t-1) is for the lagged period, $\lambda_{0}$ to $\lambda_{6}$ is the long-run coefficient. The bound test for examining the long-run association among variables can be conducted using $\mathrm{F}$ tests. The critical approximate values of $F$ test can be obtained [7, 62]. The null hypothesis of no cointegration among variables in equation (2) is $\theta_{11}, \ldots \theta_{44}=0$; and the alternative hypothesis is $\theta_{11}, \ldots . \theta_{55} \neq 0$.

Table 1. Proxy for financial development index

\begin{tabular}{ccc}
\hline Variable & Measurement & Reference \\
\hline & Domestic credit to the private sector & Rao and Hassan [57]; Ayadi, Arbak [58]; \\
Financial & Growth in bank credit & A59] \\
development & Market capitalization & {$[17,60]$} \\
& Domestic credit provided by the banking to GDP & [58]; \\
FD index & Financial development index construct by applying Principal Component Analysis \\
Remittances & Remittances \% GDP \\
Gross capital & Gross capital formation as a \% of GDP \\
formation & Inflows of FDI as a \% of GDP & \\
FDI & Int
\end{tabular}


Once the long-run association is established, the next two steps need to be executed to estimate the long-run and short-run coefficients of the proposed ARDL models. The long-run ARDL ( $, \mathrm{n}, \mathrm{q}, \mathrm{t}, \mathrm{v}, \mathrm{x}, \mathrm{p}$ ) equilibrium model is as follows

$$
\begin{gathered}
\ln F D_{t}=\sigma_{0}+\sum_{k=1}^{m} \beta_{k} \ln (R)_{t-k}+ \\
+\sum_{k=0}^{n} \gamma_{k} \ln (G C F)_{t-k}+\sum_{k=0}^{q} \delta_{k} \ln (F D I)_{t-k}++\varepsilon_{t}
\end{gathered}
$$

According to M. Hashem, the optimal lag length of ARDL model estimation is determined by considering the Akaike Information Criterion (AIC. Using time-series data for the study, according to Pesaran, Shin [63], the maximum lag length is 2 . The short-run elasticities can be derived by formulating an error correction model as follow.

$$
\begin{gathered}
\Delta \ln (F D)_{t}=\sigma_{0}+\sum_{k=1}^{n} \beta_{k} \Delta \ln (F D)_{t-k}+ \\
+\sum_{k=0}^{n} \gamma_{k} \Delta \ln (R)_{t-k}+\sum_{k=0}^{n} \delta_{k} \Delta \ln (G C F)_{t-k}+ \\
+\sum_{k=0}^{n} \mu_{k} \Delta \ln (F D I)_{t-k}+\varphi E C T_{t-1}+\omega_{t}
\end{gathered}
$$

Where the error correction term can be express as:

$$
\begin{gathered}
E C T_{t}=\ln (F D)_{t}-\sigma_{0}-\sum_{k=1}^{m} \beta_{k} \ln (F D)_{t-k}- \\
-\sum_{k=0}^{n} \gamma_{k} \ln (R)_{t-k}-\sum_{k=0}^{q} \delta_{k} \ln (G C F)_{t-k}- \\
-\sum_{k=0}^{t} \mu_{k} \ln (F D I)_{t-k}
\end{gathered}
$$

It is expected that the coefficient of ECT is negative and statistically significant to explain the speed of adjustment towards equilibrium. To ascertain the goodness of fit of the ARDL model, the diagnostic and stability tests are also conducted through serial correlation, functional form, normality, and Heteroskedasticity associated with the model. The stability tests of the regression coefficients were also performed.

Since its inception, the concept of nonlinearity by Shin, $\mathrm{Yu}$ [9] has been in the apex state in gauging the conventional nexus with asymmetry shocks of target-independent variables. In recent times, nonlinear formwork has been extensively applied to detect asymmetric impacts in the long and short run. Considering nonlinear framework, the author rewrites the equation (6) in asymmetric by incorporating asymmetric shocks in remittances inflows in selected countries as follows:

$$
\begin{aligned}
& \Delta \ln F D_{t}=\alpha_{0}+\sum_{i=1}^{n} \mu_{1} \Delta \ln F D_{t-i}+\sum_{i=0}^{m}\left(\mu_{2}^{+} \Delta \ln R^{+}{ }_{t-i}+\right. \\
& \left.+\mu_{2}^{-} \Delta \ln R^{-}{ }_{t-i}\right)+\sum_{i=0}^{m}\left(\mu_{2}^{+} \Delta \ln G C F^{+}{ }_{t-i}+\mu_{2}^{-} \Delta \ln G C F^{-}{ }_{t-i}\right)+
\end{aligned}
$$

$$
\begin{aligned}
& \sum_{i=0}^{m}\left(\mu_{2}^{+} \Delta \ln F D I^{+}{ }_{t-i}+\mu_{2}^{-} \Delta \ln F D I^{-}{ }_{t-i}\right)+ \\
& +\left(\gamma_{1}^{+} \ln {R^{+}}_{t-1}+\gamma_{1}^{-} \ln R^{-}{ }_{t-1}\right)+ \\
& +\left(\gamma_{2}^{+} \ln G C F^{+}{ }_{t-1}+\gamma_{2}^{-} \ln G C F^{-}{ }_{t-1}\right)+ \\
& +\left(\gamma_{2}^{+} \ln F D I^{+}{ }_{t-1}+\gamma_{2}^{-} \ln F D I^{-}{ }_{t-1}\right)+\omega_{t}
\end{aligned}
$$

Where,

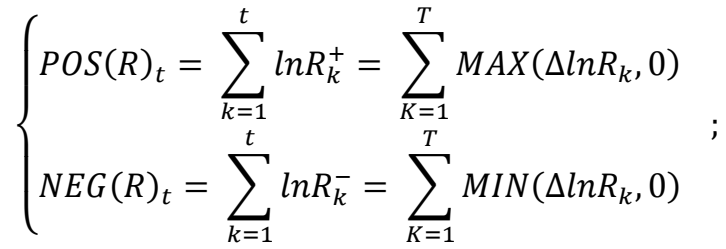

$$
\begin{aligned}
& \left\{\begin{array}{l}
\operatorname{POS}(G C F)_{t}=\sum_{k=1}^{t} \ln G C F_{k}^{+}=\sum_{K=1}^{T} \operatorname{MAX}\left(\Delta \ln G C F_{k}, 0\right) \\
N E G(G C F)_{t}=\sum_{k=1}^{t} \ln G C F_{k}^{-}=\sum_{K=1}^{T} M I N\left(\Delta \ln G C F_{k}, 0\right)
\end{array}\right. \\
& ;\left\{\begin{array}{l}
P O S(F D I)_{t}=\sum_{k=1}^{t} \ln F D I_{k}^{+}=\sum_{K=1}^{T} M A X\left(\Delta \ln F D I_{k}, 0\right) \\
N E G(F D I)_{t}=\sum_{k=1}^{t} \ln F D I_{k}^{-}=\sum_{K=1}^{T} M I N\left(\Delta \ln F D I_{k}, 0\right)
\end{array}\right.
\end{aligned}
$$

To established directional causality between financial innovation, money supply, interest rate, remittance, and stock price, we applied the non-causality test proposed by Toda and Yamamoto [64]. The Toda and Yamamoto (1995) causality test is based on the idea of Vector autoregressive at level $\left(P=K+D_{\max }\right)$ with correct VAR order $K$ and $d$ extra lag, where $d$ represents the maximum order of integration of time series.

$$
\begin{gathered}
F D_{t}=\alpha_{0}+\sum_{i=1}^{k} \beta_{1 i} F D_{t-i}+\sum_{j=k+1}^{d_{\max }} \beta_{2 j} F D_{t-j}+ \\
+\sum_{i=1}^{k} \gamma_{1 i} R_{t-i}+\sum_{j=k+1}^{d_{\max }} \gamma_{1 j} R_{t-j}+\sum_{i=1}^{k} \varphi_{1 i} G C F_{t-i}+ \\
+\sum_{j=k+1}^{d_{\max }} \varphi_{1 j} G C F_{t-j}+\sum_{i=1}^{k} \varphi_{1 i} F D I_{t-i}+ \\
+\sum_{j=k+1}^{d_{\max }} \varphi_{1 j} F D I_{t-j}
\end{gathered}
$$

\section{Empirical Model Estimation and Interpretation}

Empirical model estimation based on time series data seeking prior detection of variables order of integration due to the selection of appropriate econometrical methodology immensely relies on the level of the variable 
of integration. The study applies the test of stationary following Dickey and Fuller [65]-ADF test, Elliott, Rothenberg [66]-GF-DLS, Phillips and Perron [67]-PP test, Kwiatkowski, Phillips [68]-KPSS test. Unit root test results are displayed in Table 2 . Study documents that variables are stationary in mixed order, implying that either variable is exposed stationary at a level or/. After a first difference, neither variable is exposed stationary after the second difference. The existing integration properties allow a bond testing approach to detect the long-run association in the empirical model.

The conventional unit root test results are subject to variables in the structural break, which produces ambiguity in estimation. Thus, to avoid ambiguity, the study performed a unit root test with structural brake following Zivot and Andrews [69], resulting in Table 3. Study documents all the variables are stationary after the first difference with structural brake, in particular, for the series of financial development (2013 in Bangladesh, 2003 in India, 2012 in Pakistan and 2000 in Srilanka), remittance (2007 in Bangladesh, 2010 in India, 2003 in Pakistan and 2011 in Srilanka), gross capital formation (2010 in Bangladesh, 2010 in India, 2013 in Pakistan and 2006 in Srilanka), and foreign direct investment (1999 in Bangladesh, 2003 in India, 2009 in Pakistan and 2002 in Srilanka).

Table 2. Results of unit root test

\begin{tabular}{ccccccccc}
\hline & ADF & GF-DLS & PP & KPSS & ADF & GF-DLS & PP & KPSS \\
& & For Bangladesh & & & \multicolumn{2}{c}{ For India } \\
FD & -1.382 & -0.819 & -0.787 & 0.9390 & -0.659 & -2.816 & -2.969 & 0.8000 \\
R & -2.294 & -0.672 & -0.654 & 0.7990 & -2.018 & -1.12 & -1.866 & 0.7800 \\
GCF & -2.525 & -1.976 & -2.929 & 0.8560 & -1.753 & -0.128 & -1.837 & 0.7130 \\
FDI & -1.812 & -1.802 & -1.346 & 0.8410 & -2.946 & -1.778 & -0.914 & 0.7360 \\
$\Delta$ FD & -7.016 & -3.6 & -3.739 & 0.1330 & -4.015 & -4.01 & -3.456 & 0.1770 \\
$\Delta \mathrm{R}$ & -7.341 & -4.334 & -5.892 & 0.1670 & -4.311 & -4.004 & -3.08 & 0.1350 \\
$\Delta$ GCF & -6.205 & -2.088 & -3.908 & 0.1700 & -4.435 & -4.977 & -4.448 & 0.0760 \\
$\Delta$ FDI & -6.572 & -4.725 & -3.915 & 0.1210 & -6.111 & -2.45 & -5.206 & 0.1410 \\
& & For Pakistan & & & & For Srilanka & \\
\hline FD & -2.78 & -0.626 & -1.927 & 0.7860 & -2.782 & -1.657 & -0.95 & 0.7840 \\
R & -2.445 & -2.68 & -2.01 & 0.8860 & -2.779 & -0.602 & -0.869 & 0.6900 \\
GCF & -2.102 & -1.432 & -1.436 & 0.9250 & -1.925 & -2.539 & -1.65 & 0.8480 \\
FDI & -2.107 & -0.183 & -1.148 & 0.9540 & -0.862 & -1.205 & -1.126 & 0.7250 \\
$\Delta$ FD & -6.181 & -4.482 & -3.426 & 0.0890 & -6.409 & -3.065 & -4.258 & 0.1320 \\
$\Delta \mathrm{R}$ & -5.374 & -4.262 & -4.016 & 0.1130 & -5.466 & -2.66 & -4.982 & 0.1130 \\
$\Delta$ GCF & -6.135 & -4.163 & -3.148 & 0.1790 & -4.576 & -3.741 & -5.447 & 0.0890 \\
$\Delta$ FDI & -6.567 & -2.08 & -4.769 & 0.1390 & -6.817 & -3.969 & -4.211 & 0.1410 \\
\hline
\end{tabular}

Note: the superscript $* * * / * * / *$ denotes the level of significant at a $1 \% / 5 \% / 105$, respectively. 
Table 3. Results of Zivot and Andrews (2002) unit root test

\begin{tabular}{|c|c|c|c|c|}
\hline & \multicolumn{2}{|c|}{ At level } & \multicolumn{2}{|c|}{ After first difference } \\
\hline & T-statistic & Time Break & T-statistic & Time Break \\
\hline \multicolumn{5}{|c|}{ Panel-A : for Bangladesh } \\
\hline FD & $-2.129(1)$ & 2000 & $-8.521(2)^{* * *}$ & 2013 \\
\hline $\mathrm{R}$ & $-2.312(2)$ & 2006 & $-6.812(1)^{* * *}$ & 2007 \\
\hline GCF & $-2.885(3)$ & 2000 & $-5.854(3)^{* * *}$ & 2010 \\
\hline FDI & $-2.58(3)$ & 1999 & $-7.844(1)^{* * *}$ & 1999 \\
\hline \multicolumn{5}{|c|}{ Panel-B : for India } \\
\hline FD & $-2.893(1)$ & 2009 & $-7.613(1)^{* * *}$ & 2003 \\
\hline $\mathrm{R}$ & $-1.963(3)$ & 2012 & $-5.144(2)^{* * *}$ & 2010 \\
\hline GCF & $-2.726(3)$ & 2009 & $-8.169(3)^{* * *}$ & 2012 \\
\hline FDI & $-2.144(1)$ & 2006 & $-6.015(4)^{* * *}$ & 2003 \\
\hline \multicolumn{5}{|c|}{ Panel-C : for Pakistan } \\
\hline FD & $-2.917(3)$ & 2002 & $-8.246(4)^{* * *}$ & 2012 \\
\hline $\mathrm{R}$ & $-2.424(1)$ & 2007 & $-6.122(1)^{* * *}$ & 2003 \\
\hline GCF & $-2.409(3)$ & 2006 & $-7.364(2)^{* * *}$ & 2013 \\
\hline FDI & $-2.433(2)$ & 2007 & $-7.703(1)^{* * *}$ & 2009 \\
\hline \multicolumn{5}{|c|}{ Panel-D : for Srilanka } \\
\hline FD & $-2.202(1)$ & 2013 & $-5.852(1)^{* * *}$ & 2000 \\
\hline $\mathrm{R}$ & $-2.158(2)$ & 2003 & $-7.822(1)^{* * *}$ & 2011 \\
\hline GCF & $-2.887(1)$ & 2009 & $-7.623(1)$ & 2006 \\
\hline FDI & $-2.377(2)$ & 2005 & $-7.965(2) * * *$ & 2002 \\
\hline
\end{tabular}

Note: $*$ and $* *$ represent significance at $1 \%$, and $5 \%$ levels respectively. The lag order is shown in parenthesis.

The following study moves to gauge the long-run association by following the ARDL bound testing approach initiated by Pesaran, Shin [7]. The results of long-run cointegration, along with long-run and short-run coefficients, are displayed in Table 4. Panel $-\mathrm{A}$ in the table reports the tested coefficient of Fpass [7], tBDM, and joint Wald test Wpass with the null hypothesis of on-cointegration. All the test statistics are statistically significant at a $1 \%$ level, implying the long-run association between remittances, capital formation, FDI, and financial development in selected south Asian countries. Once the long-run association reveals, the study moves to evaluate the impacts of remittances, capital formation, and FDI on financial development.

Panel - B in Table 4 exhibits the results of long-run coefficients. Study findings document positive and statistically significant effects running from remittances to financial development in Bangladesh (a coefficient of 0.112), in India (a coefficient of 0.241), in Pakistan (a coefficient of 0.084), and Srilanka (a coefficient of 0.094). According to coefficients, a $10 \%$ increase in remittances inflows can augment the speed of financial development by $1.12 \%$ in Bangladesh, by $2.11 \%$ in India, $0.84 \%$ in Pakistan, and by $0.94 \%$ in Srilanka, respectively. The study findings are supported by existing literature [29, 70-72]. Finding suggests that inflows of remittances assist in ensuring substantial money flows in the financial system, thus augmenting the financial transaction in the economy. Eventually, the financial sector has experienced growth in financial movements. Remittances accelerate financial activities by channeling money flows into household consumption [73].

Moreover, the growth of domestic capital formation documents a positive, statistically significant association with the measures of financial development. More precisely, a $10 \%$ increase in domestic capital formation can accelerate the present state of financial development by $0.48 \%$ in Bangladesh, $0.78 \%$ in India, $0.15 \%$ in Pakistan, and $0.84 \%$ in Srilanka. It is in the line with Bekhet, Yasmin [74] and Guiso, Sapienza [75]. Additionally, the nexus between foreign direct investment and financial development documents a positive statistically significant association available in Bangladesh (a coefficient of 0.095), in India (a coefficient of 0.084), in Pakistan (a coefficient of 0.0442), and Srilanka (a coefficient of 0.0227). Study findings in line with existing literature see, for instance [40]. Study findings suggest a $10 \%$ improvement in FDI inflows can augment financial development by $0.95 \%$ in Bangladesh, $0.84 \%$ in India, $0.44 \%$ in Pakistan, and $0227 \%$ in Srilanka. It is apparent here that Srilanka has been experiencing the most negligible effects from FDI inflows on financial 
development compared to other nations. The coefficient of the interactive term $(\mathrm{R} * \mathrm{GCF})$ exposes a positive, statistically significant (a coefficient of 0.041) linkage with financial development, indicating that the growth of the financial sector can be intensified through capital accumulation. So, it is inferable that remittance has a capacity of capital accumulation in the economy, thus assisting in thriving the financial sector development.

For the short-run, the coefficient of error correction in Bangladesh (a coefficient of -0.635), in India (a coefficient of -0.468), in Pakistan (a coefficient of -0.511), and in Srilanka (a coefficient of -0.361) is negative and statistically significant at $1 \%$ significance level, indicating the presence of long-run convergence in the equation due to any prior period shock in regressors. Study findings suggest that according to the coefficient of ECT, the prior period shock is to be corrected by $63.5 \%$ in Bangladesh, by $46.8 \%$ in India, by $51.1 \%$ in Pakistan, and by $36.1 \%$ in Srilanka with one year period. Refers to elasticity running from remittance to financial development, the study establishes a positive statistically significant relationship in Bangladesh (a coefficient of 0.015), in India (a coefficient of 0.0084), in Pakistan (a coefficient of
0.0091), and Srilanka (a coefficient of 0.0021). Remittance impact in the short run is less intense than the long-run effects on financial development in the south Asian economy. Furthermore, the study exposes the positive statistically significant association between gross capital formation and financial development, i.e., in Bangladesh (a coefficient of 0.016), in India (a coefficient of 0.0045), in Pakistan (a coefficient of 0.0084), and Srilanka (a coefficient of 0.0022) and the association between FDI and financial development, i.e., in Bangladesh (a coefficient of 0.099), in India (a coefficient of 0.0041), in Pakistan (a coefficient of 0.0052), and Srilanka (a coefficient of 0.0025). In addition, the interactive term $\mathrm{R}^{*} \mathrm{GCF}$ is positive but statistically insignificant.

The estimated empirical model passes several residual diagnostic tests and results of residual diagnostic test reports in Panel $-\mathrm{D}$ of Table 4. The study confirms that the empirical model is free from serial correlation, residuals are normally distributed, and there is no issue regarding heteroskadacity. The test statistics of RESET confirm model stability in output estimation.

Table 4. Results of ARDL bound testing

\begin{tabular}{|c|c|c|c|c|}
\hline \multicolumn{5}{|c|}{ Long-run cointegration } \\
\hline & Bangladesh & India & Pakistan & Srilanka \\
\hline Fpass & $10.72 * * *$ & 11.045 & 8.485 & 9.757 \\
\hline tBDM & 9.881 & 11.662 & 8.365 & 12.917 \\
\hline Wpass & -10.157 & -16.169 & -8.123 & -14.502 \\
\hline \multicolumn{5}{|c|}{ Panel-B: long-run coefficients } \\
\hline Variable & Coefficient & Coefficient & Coefficient & Coefficient \\
\hline $\mathrm{R}$ & $0.112 * * *$ & $0.241^{* * *}$ & $0.084 * * *$ & $0.094 * *$ \\
\hline GCF & $0.048^{* * *}$ & $0.078^{* * *}$ & $0.015^{* *}$ & $0.084 * *$ \\
\hline $\mathrm{R} * \mathrm{GCF}$ & $0.041^{* * *}$ & $0.021^{* * *}$ & $0.0244^{* * *}$ & $0.0411^{* * *}$ \\
\hline FDI & $0.095^{* * *}$ & $0.084 * *$ & $0.0442^{* * *}$ & $0.0227^{*}$ \\
\hline \multicolumn{5}{|c|}{ Panel-C: short-run coefficients } \\
\hline ECT(-1) & $-0.635 * * * *$ & $-0.468 * * *$ & $-0.511 * * *$ & $-0.361 * * *$ \\
\hline $\mathrm{C}$ & $-3.826 * * *$ & -1.251 & $2.051^{* *}$ & -2.512 \\
\hline @TREND & $0.012 * * *$ & 0.0510 & 0.0047 & 0.0241 \\
\hline $\mathrm{R}$ & $0.015^{* * *}$ & $0.0084 * * *$ & $0.0091^{* * *}$ & $0.0021 * * *$ \\
\hline GCF & $0.016^{* * *}$ & $0.0045^{* *}$ & $0.0084 * *$ & $0.0022 *$ \\
\hline $\mathrm{R} * \mathrm{GCF}$ & 0.009 & 0.0051 & 0.0084 & 0.0041 \\
\hline FDI & $0.099 * * *$ & $0.0041^{* *}$ & $0.0052 * *$ & $0.0025^{* *}$ \\
\hline \multicolumn{5}{|c|}{ Panel -D: Residual diagnostic test } \\
\hline$x_{\text {Auto }}^{2}$ & 0.102 & 0.854 & 0.781 & 0.435 \\
\hline$x_{\mathrm{Het}}^{2}$ & 0.904 & 0.958 & 0.274 & 0.872 \\
\hline$x_{\text {Nor }}^{2}$ & 0.314 & 0.913 & 0.448 & 0.36 \\
\hline$x_{R E S E T}^{2}$ & 0.153 & 0.372 & 0.233 & 0.136 \\
\hline
\end{tabular}

Note: the superscript $* * * / * * / *$ denotes the level of significant at a $1 \%, 5 \%$, and $10 \%$ respectively. 
Model estimation passes through several diagnostic tests, and their results are displayed in Panel -D of Table 7. Test statistics of diagnostic tests ascertain that the empirical model is free for serial correlation, issues of heteroskadacity, and the error terms are normally distributed. Moreover, following Pesaran, Shin [7] study performs a model stability test with CUSUM and CUSUM of Square test (see figure $-1 \& 8$, which confirms the coefficient estimation model's internal consistency.

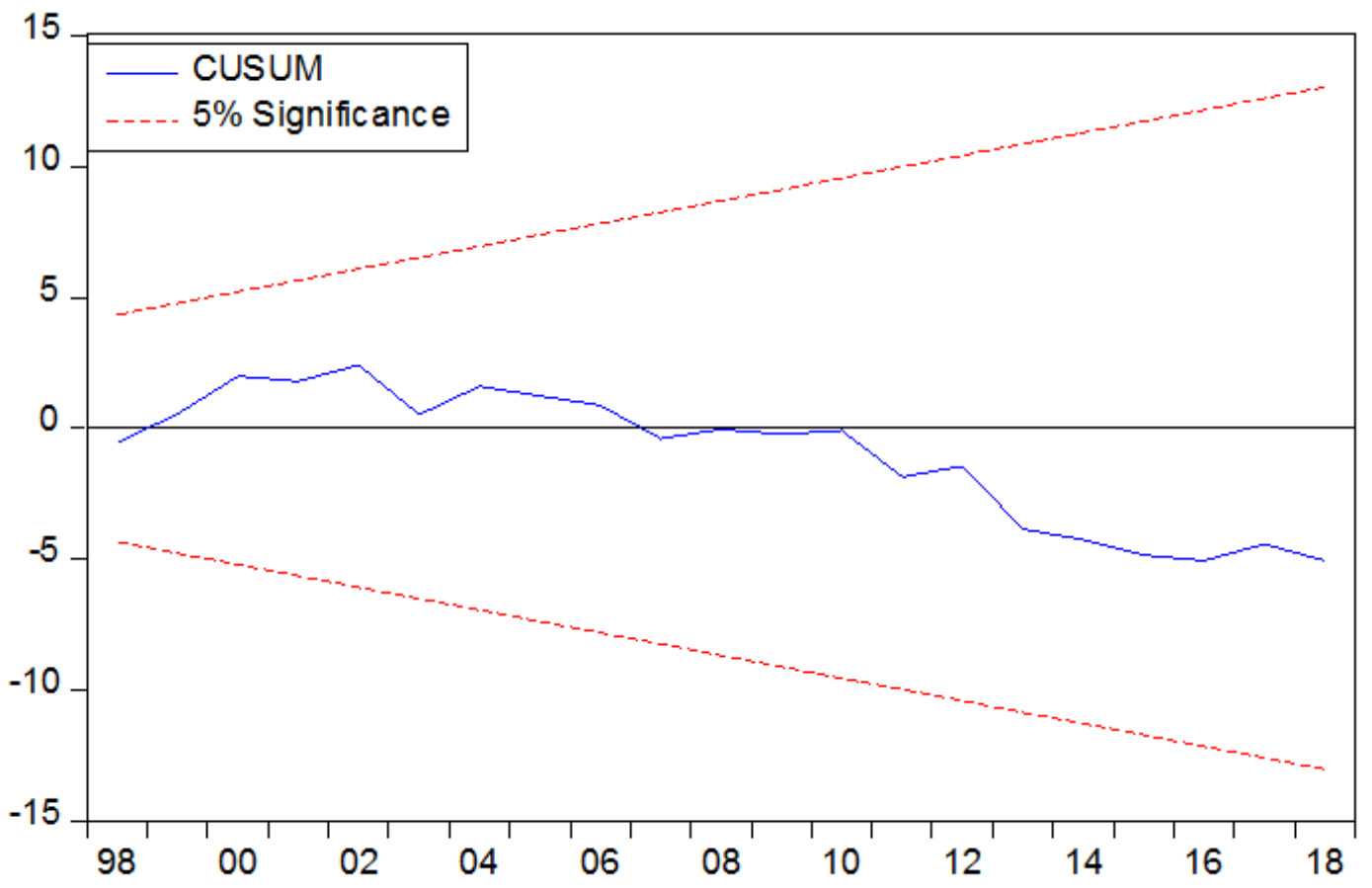

Figure 1. CUSUM test for Bangladesh

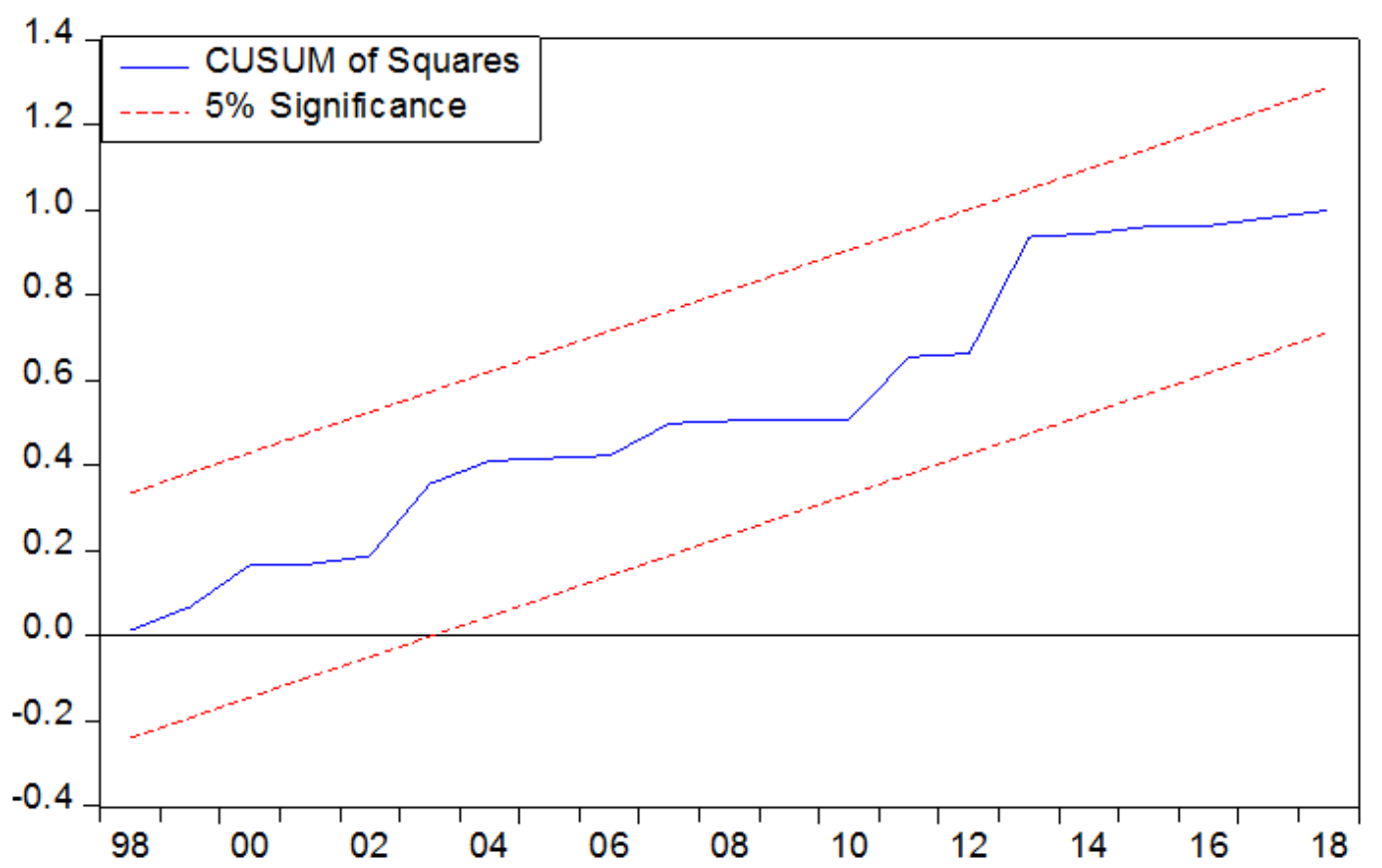

Figure 2. CUSUM of square for Bangladesh 
A Symmetric and Asymmetric Investigation for Selected South Asian Countries

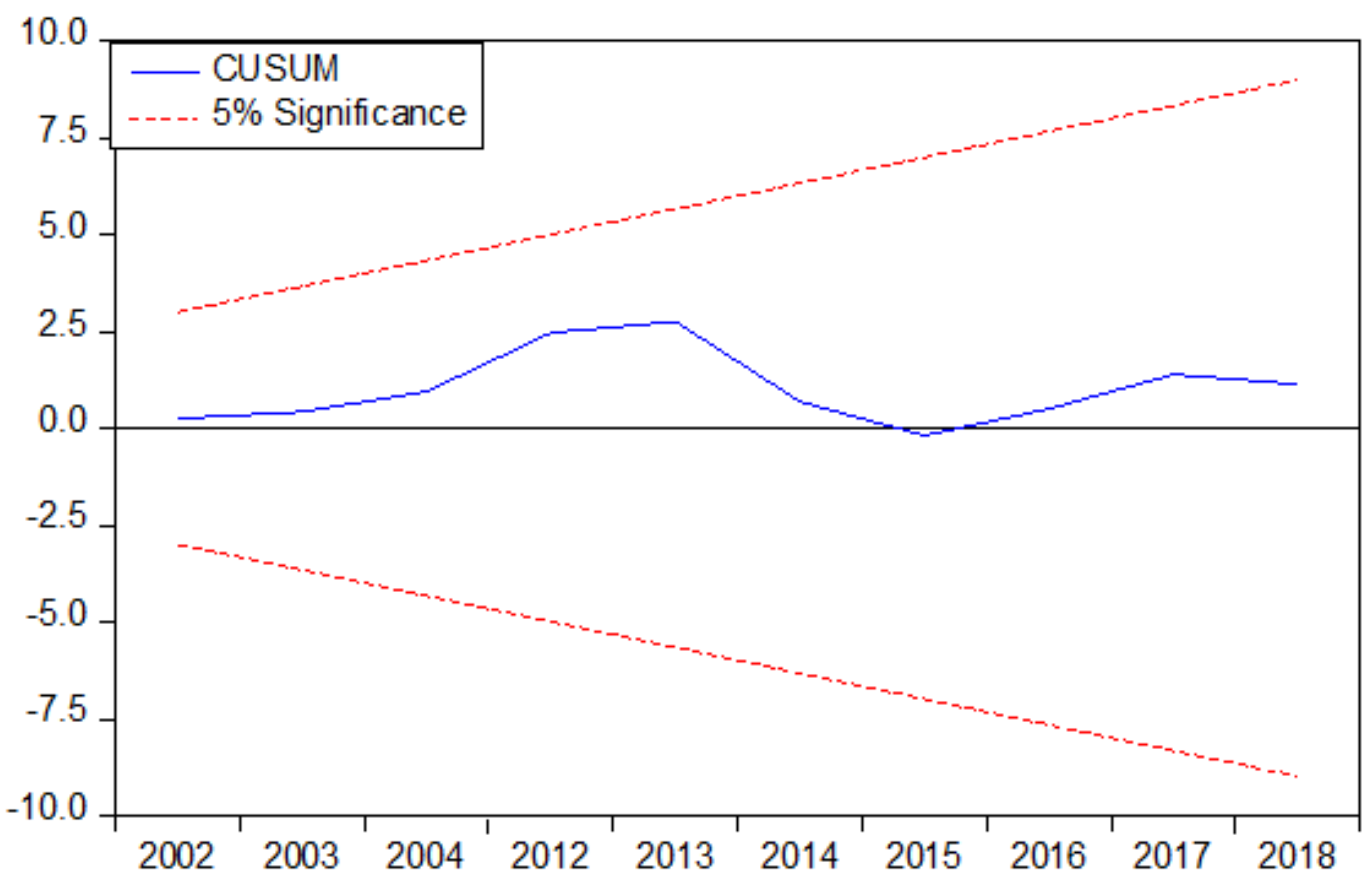

Figure 3. CUSUM test for India

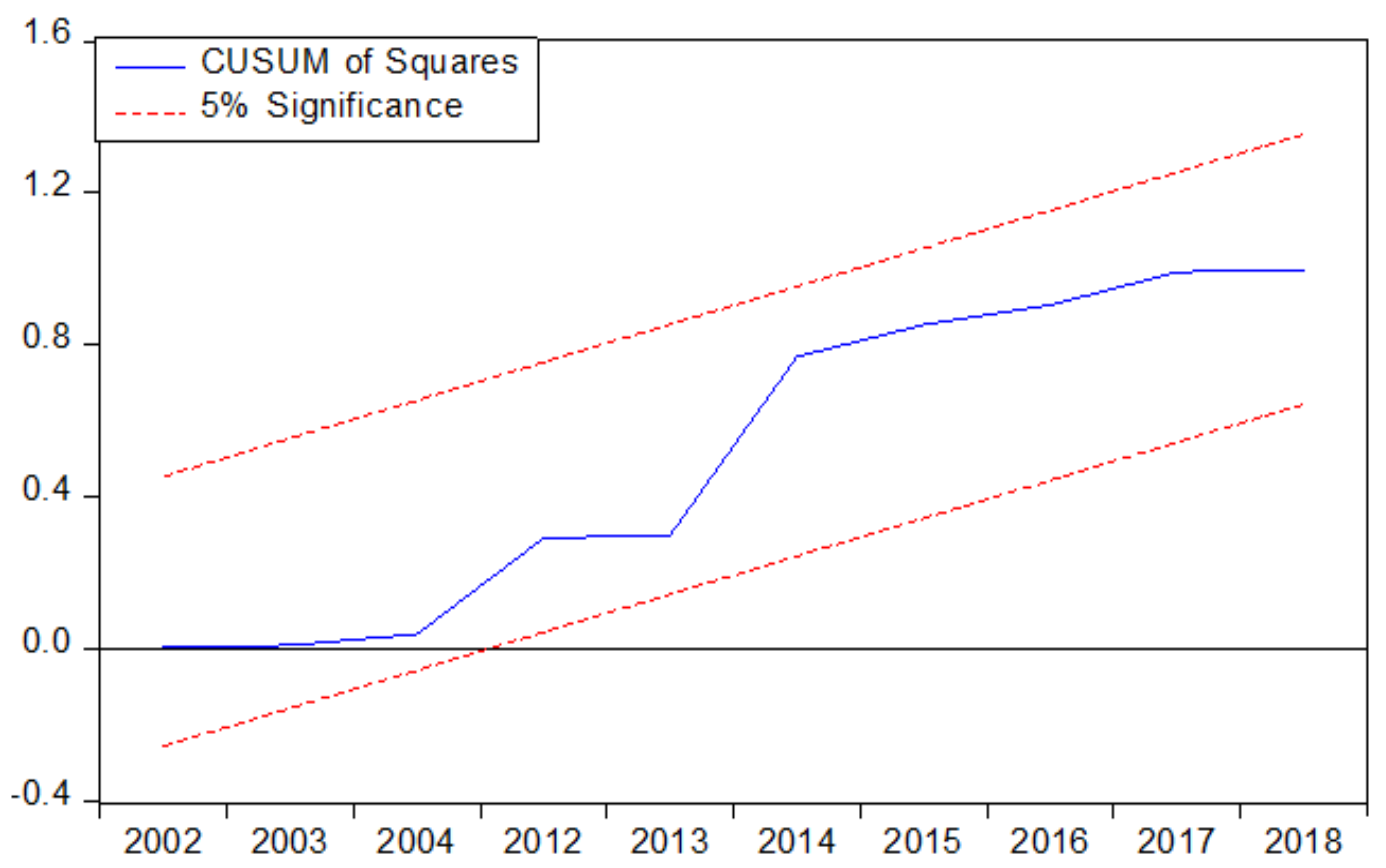

Figure 4. CUSUM of square for India 


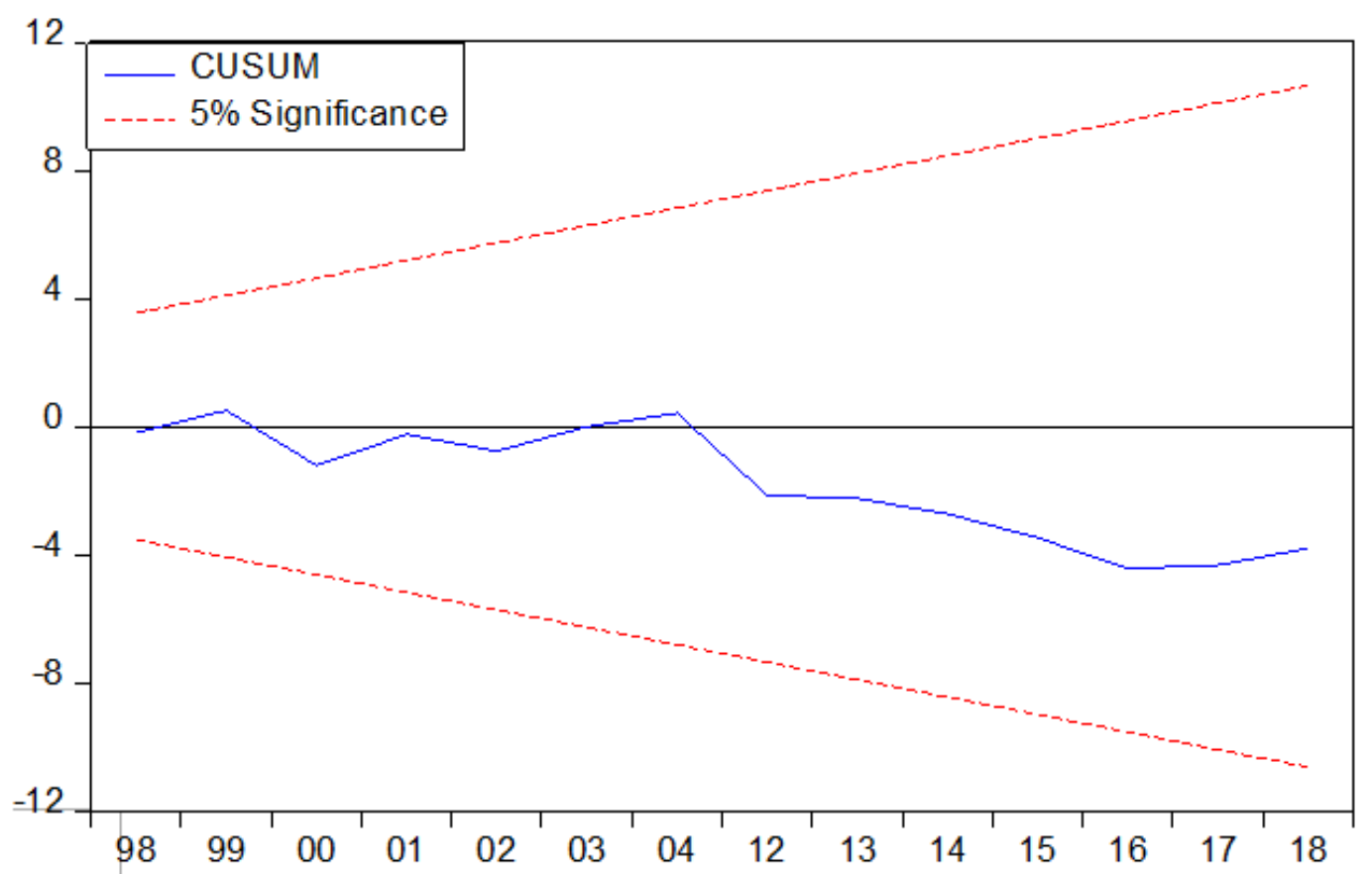

Figure 5. CUSUM test for Pakistan

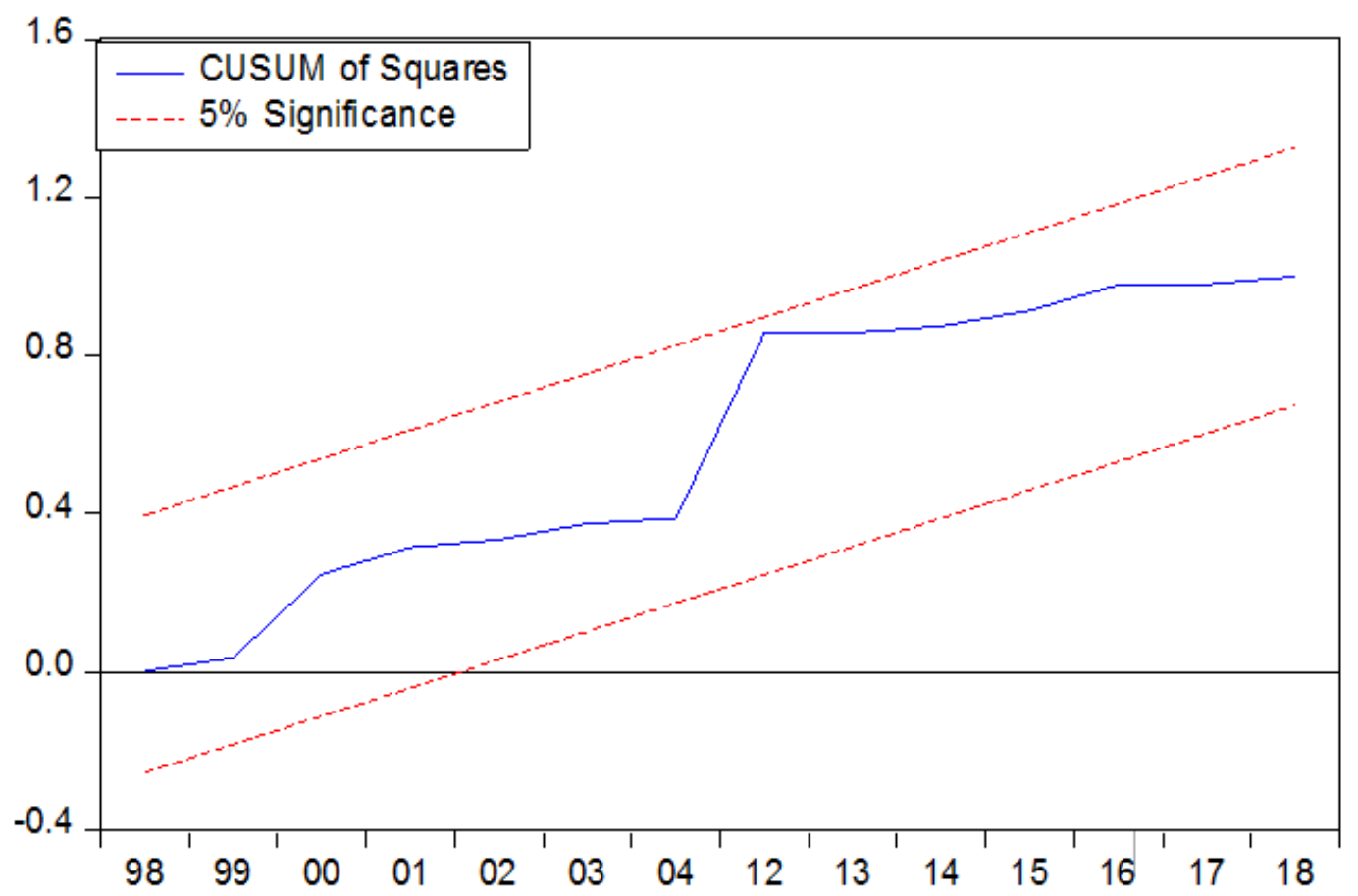

Figure 6. CUSUM of square for Pakistan 


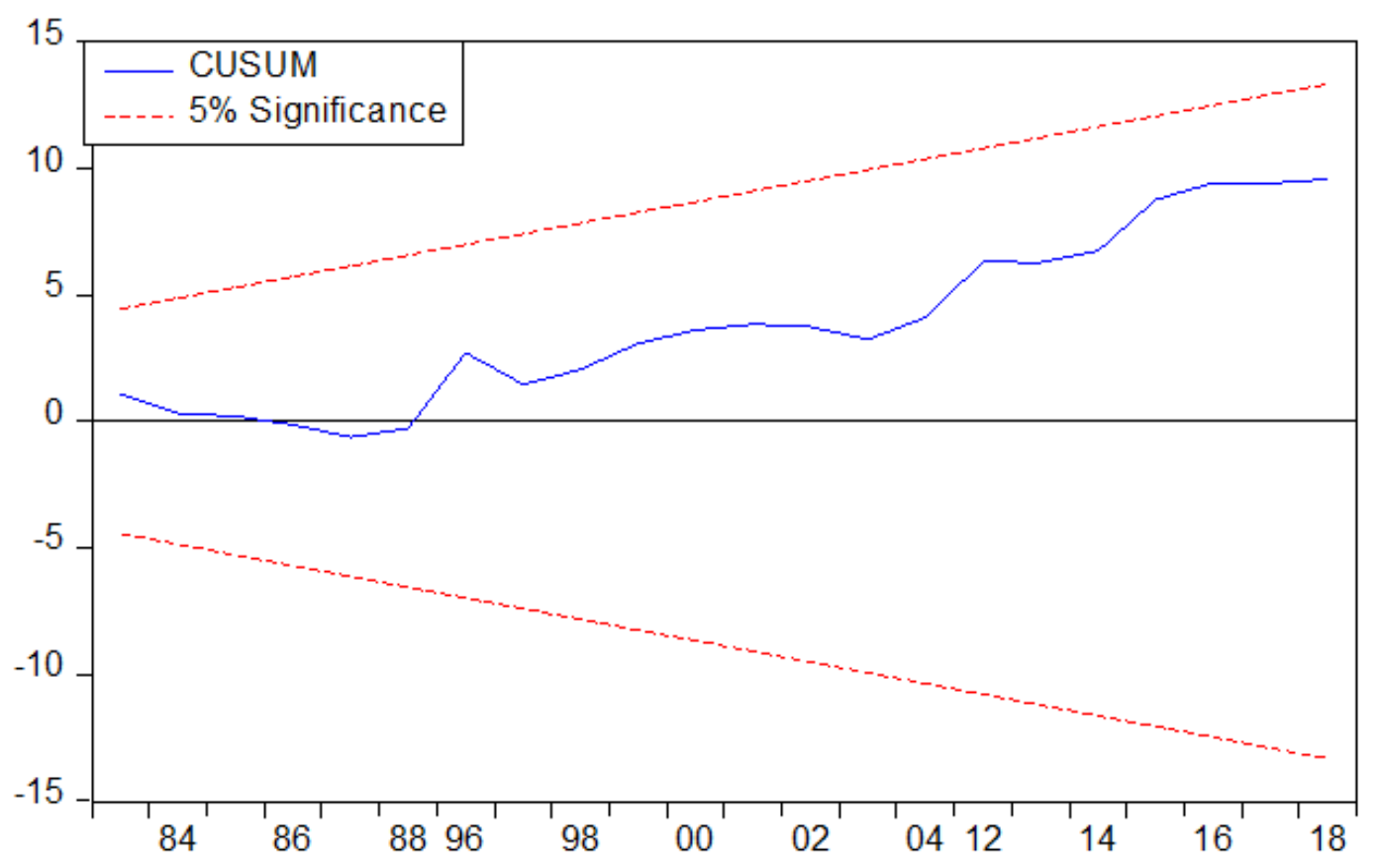

Figure 7. CUSUM test for SriLanka

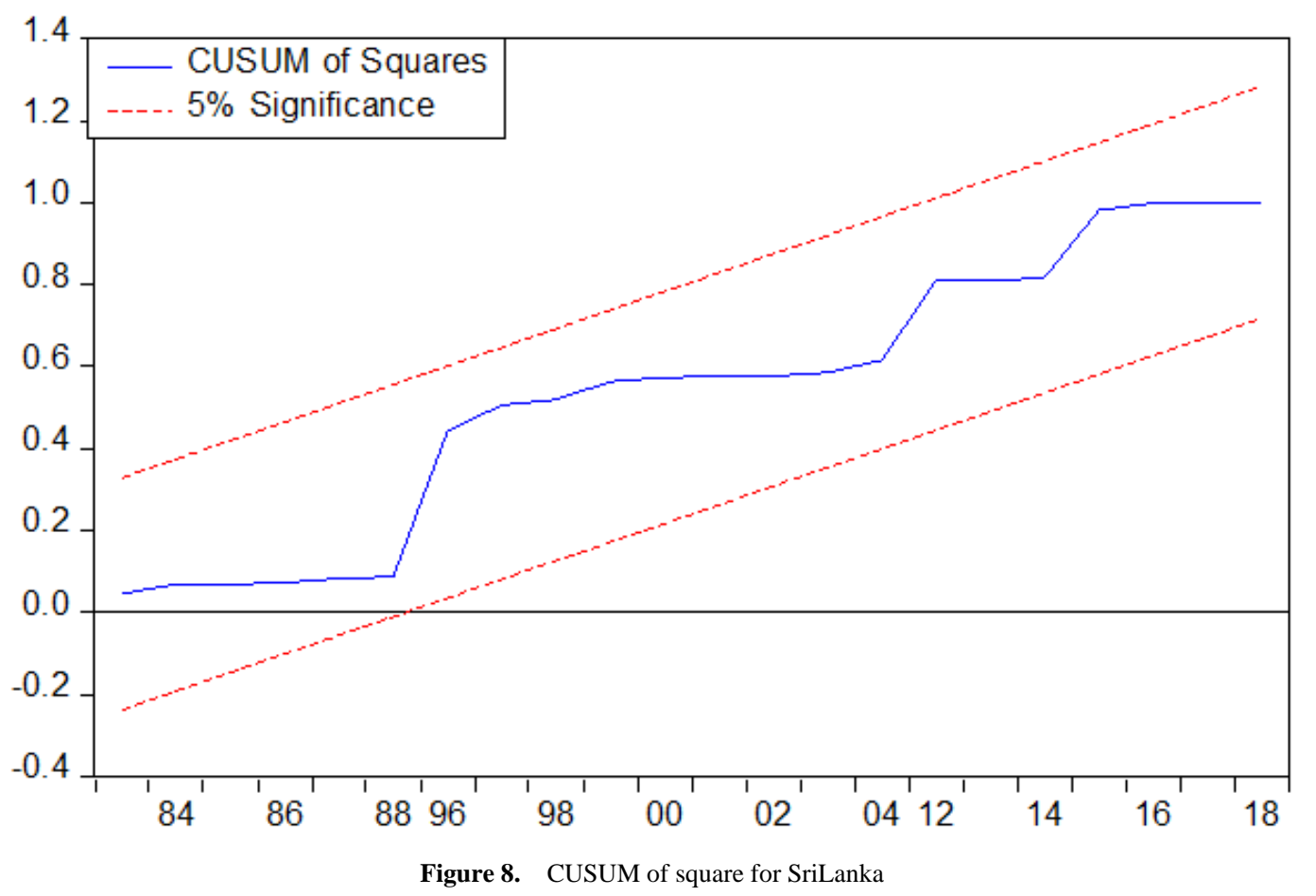

Next, the study moves to evaluate the asymmetric effects of remittances, gross capital formation, FDI on financial development in Bangladesh, India, Pakistan, and Srilanka by performing nonlinear ARDL, initiated by Shin, $\mathrm{Yu}$ [9]. Table 5 displays the nonlinear model estimation results, consisting of long-run asymmetric cointegration and symmetry test in the panel $-\mathrm{A}$, long-run coefficients in the panel $-\mathrm{B}$, the short-run coefficient in panel-C residual diagnostic test in Panel-D.

Regarding the long-run asymmetric cointegration, it is apparent that the test statistics of $\mathrm{F}_{\text {pass }}, \mathrm{W}_{\text {pass, }}$, and $\mathrm{t}_{\mathrm{BMD}}$ are statistically significant at a1\% level, indicating the asymmetric cointegration between remittances, gross capital formation, FDI, and financial development in selected south Asian countries. Furthermore, the study performed a standard Wald test to ascertain the possible long-run and short asymmetry in the empirical model running from R, GCF, and FDI to financial development. Study documents the test statistics of Wald test are statistically significant at a $1 \%$ level, which is revealed for 
both long-run and short-run asymmetric association. Now proceeds to evaluate the asymmetric coefficients for both long-run (see panel -B) and short-run (see, panel-C).

For the long-run, asymmetric effects of remittances that are positive and negative shocks in the long run (see panel B) exhibit a positive and statistically significant tie with the proxy measures of financial development of Bangladesh (a coefficient of 0.3819 for positive and a coefficient of 0.0675 of negative shock), of India (a coefficient of 0.4537 for positive variation and a coefficient of 0.1876 for negative shock), of Pakistan (a coefficient of 0.3794 for positive shocks and a coefficient of 0.2334 for negative innovation), of Srilanka (a coefficient of 0.3543 for positive development and a coefficient of 0.1769 for adverse shocks). Study findings suggest the critical aspect of remittances for sustainable financial development for selected south Asian economies, implying that continual inflows of migrant remittances can fuel financial development. According to asymmetric magnitudes, the positive shocks produce a higher intensity in thriving the present state of financial development and pushing for sustainable financial development. More specifically, $10 \%$ shocks in remittances inflows can intensify the process of financial development by $3.819 \%$ in Bangladesh, by $4.537 \%$ in India, by $3.794 \%$ in Pakistan, and by 3.543 in Srilanka, respectively. Simultaneously, the same rate of adverse shocks in remittances can result in unfavorable growth in financial development by $0.675 \%$ in Bangladesh, by $1.879 \%$ in India, by $2.334 \%$ in Pakistan, and by $1.769 \%$ in Srilanka.

Asymmetric shocks of gross capital formation on financial development expose a positive statistically significant association. More precisely, a $10 \%$ positive innovation in gross capital formation can enhance financial development by $1.250 \%$ in Bangladesh, $1.658 \%$ in India, $1.653 \%$ in Pakistan, and $1.442 \%$ in Srilanka, respectively. A $10 \%$ negative shock can be adversely caused by dwindling the present state of financial development by $0.348 \%$ in Bangladesh, $0.547 \%$ in India, $1.528 \%$ in Pakistan, and $0.662 \%$ in Srilanka. Study findings advocate that the process of capital accumulation plays an essential role in financial thrive.

Finally, FDI asymmetric impact on financial development that is positive and negative shocks in FDI inflows. The study reveals positive statistically significant links with financial development and asymmetric shocks of FDI. Precisely, a 10\% positive variation in FDI inflows can entice the present speed of financial development by $2.080 \%$ in Bangladesh, by $1.467 \%$ in India, by $1.283 \%$ in Pakistan, and by $1.308 \%$ in Srilanka, respectively. Study findings postulate that foreign investors' participation in the financial system ensured investment availability and channelization. Thus, it persistently demands financial efficiency in financial intermediation and operational efficiency [42]. Whereas a $10 \%$ negative innovation in FDI inflows can restrict Bangladesh's financial development by $0.203 \%$, India by $0.074 \%$, Pakistan by $1.902 \%$, and Srilanka by $1.721 \%$, respectively.

For the short-run assessment, the coefficient of error correction term is negative statistically significant at a $1 \%$ level of significance which ascertains the long-run convergence due to short-run shock in explanatory variables in the equation, according to the ECT coefficient, yearly shock adjustment towards long-run equilibrium in Bangladesh by $12.8 \%$, India by $25.1 \%$, Pakistan by $23.9 \%$ and in Srilanka by $20.9 \%$, respectively. According to asymmetric shocks in R, GCF and FDI disclose statistically insignificant in majority classes. However, the statistically significant linked documents with positive shocks in remittances, i.e., for Bangladesh (a coefficient of 0.044), for India (a coefficient of 0.0035), for Pakistan (a coefficient of 0.0067), and Srilanka (a coefficient of 0.0078), negative shocks in remittance, i.e., for Bangladesh (a coefficient of 0.0032) and Pakistan (a coefficient of 0.0012). Furthermore, there is a statistically positive tie with positive shock in gross capital formation in Bangladesh (a coefficient of 0.0015) and Srilanka (a coefficient of 0.0246) and negative shock in gross capital formation for India (a coefficient of 0.0032). Positive shocks in FDI establishe a negative link with the financial development of Bangladesh (a coefficient of -0.084) but a positive connection for Pakistan (a coefficient of 0.0094) and Srilanka (a coefficient of 0.0278).

The estimated empirical model passes through several residual diagnostic tests and results of residual diagnostic test reports in Panel -D of Table 5 Results of nonlinear ARDL estimation. The study confirms that the empirical model is free from serial correlation, residuals are normally distributed, and there is no issue regarding heteroskadacity. The test statistics of RESET confirm model stability in output estimation. 
Table 5. Results of nonlinear ARDL estimation

\begin{tabular}{|c|c|c|c|c|}
\hline & \multicolumn{4}{|c|}{ Model estimation } \\
\hline & Bangladesh & India & Pakistan & Srilanka \\
\hline \multicolumn{5}{|c|}{ Panel-A: long-run asymmetric cointegration } \\
\hline Fpass & 10.703 & 12.748 & 9.526 & 8.99 \\
\hline $\mathrm{tBDM}$ & 10.631 & 12.613 & 11.688 & 11.941 \\
\hline Wpass & -11.116 & -10.023 & -9.316 & -14.19 \\
\hline$W_{L R}^{R}$ & $14.6433^{* * *}$ & $6.5576 * * *$ & $14.3947 * * *$ & $6.7816^{* * *}$ \\
\hline$W_{L R}^{G C F}$ & $11.7996^{* * *}$ & $9.5336^{* * *}$ & $6.8091 * * *$ & $11.2966^{* * *}$ \\
\hline$W_{L R}^{F D I}$ & $5.9698 * * *$ & $9.4204 * * *$ & $11.5831 * * *$ & $7.2241 * * *$ \\
\hline$W_{S R}^{R}$ & $6.7429 * * *$ & $13.4866^{* * *}$ & $12.2335 * * *$ & $7.0585 * * *$ \\
\hline$W_{S R}^{G C F}$ & $8.1604 * * *$ & $13.9144 * * *$ & $13.7712 * * *$ & $14.1982 * * *$ \\
\hline$W_{S R}^{F D I}$ & $12.6225^{* * *}$ & $9.6603 * * *$ & $7.1054 * * *$ & $8.0163 * * *$ \\
\hline \multicolumn{5}{|c|}{ Panel-B: Long-run coefficients } \\
\hline $\mathrm{R}^{+}$ & $0.3819^{* * *}$ & $0.4537 * * *$ & $0.3794 * * *$ & $0.3543^{* * *}$ \\
\hline $\mathrm{R}^{-}$ & $0.0675^{* * *}$ & $0.1879 * * *$ & $0.2334 * * *$ & $0.1769^{* * *}$ \\
\hline $\mathrm{GCF}^{+}$ & $0.1250^{* * *}$ & $0.1658^{* * *}$ & $0.1653^{* *}$ & $0.1442^{* * *}$ \\
\hline $\mathrm{GCF}^{-}$ & $0.0348 * * *$ & $0.0547 * * *$ & $0.1528 * * *$ & $0.0662 * * *$ \\
\hline $\mathrm{FDI}^{+}$ & $0.2080 * * *$ & $0.1467^{* * *}$ & $0.1283^{* * *}$ & $0.1308^{* *}$ \\
\hline FDI $^{-}$ & $0.0203^{* * *}$ & $0.0074 * * *$ & $0.1902 * * *$ & $0.1721^{* * *}$ \\
\hline \multicolumn{5}{|c|}{ Panel-C: Short-run coefficients } \\
\hline$\zeta$ & $-0.128 * * *$ & $-0.251 * * *$ & $-0.239 * * *$ & $-0.209 * * *$ \\
\hline Constant & $-0.871 * * *$ & 1.053 & 1.024 & 0.7146 \\
\hline Trend & $-0.029 * * *$ & 0.0187 & -0.0131 & 0.0053 \\
\hline $\mathrm{R}^{+}$ & $0.044 * * *$ & $0.0035^{* * *}$ & $0.0067 * *$ & $0.0078^{* * *}$ \\
\hline $\mathrm{R}^{-}$ & $0.032 * * *$ & 0.0188 & $0.0012 * * *$ & 0.0077 \\
\hline $\mathrm{GCF}^{+}$ & $0.0015^{* *}$ & 0.0137 & 0.0043 & $0.0246^{* *}$ \\
\hline $\mathrm{GCF}^{-}$ & -0.004 & $0.0032 * * *$ & 0.011 & -0.0021 \\
\hline $\mathrm{FDI}^{+}$ & $-0.084 * *$ & 0.0319 & $0.0094 * *$ & $0.0278 * *$ \\
\hline $\mathrm{FDI}^{-}$ & 0.0003 & 0.0294 & 0.0122 & -0.0146 \\
\hline \multicolumn{5}{|c|}{ Residual diagnostic test } \\
\hline$x_{\text {Auto }}^{2}$ & 0.611 & 0.498 & 0.55 & 0.943 \\
\hline$x_{\mathrm{Het}}^{2}$ & 0.123 & 0.531 & 0.337 & 0.985 \\
\hline$x_{\text {Nor }}^{2}$ & 0.791 & 0.677 & 0.417 & 0.623 \\
\hline \multirow[t]{2}{*}{$x_{R E S E T}^{2}$} & 0.666 & 0.956 & 0.529 & 0.053 \\
\hline & CUSUM & Stable (fig-3) & CUSUM of square & Stable (Fig-4) \\
\hline
\end{tabular}

The results of the causality test are displayed in Table 6. Study findings establish several directional causalities running in empirical estimation. The study discloses the evidence favoring the feedback hypothesis for bidirectional causality to explain the causality between financial development and remittances $[\mathrm{FD} \leftarrow \rightarrow \mathrm{R}]$ in all four countries. Study findings supported by the exiting literature see [10-12]. Even though remittances are the source of financial sector growth, more extraordinary records of remittances may be accounted since better financial development leads to higher measures of money sent via formal channels [13].

Moreover, the feedback hypothesis also reveals to explain the causality between gross capital formation and financial development [FD $\leftarrow \rightarrow \mathrm{GCF}$ ], inflows of FDI and financial development [FDI $\leftarrow \rightarrow F D$ ], which is available or Bangladesh and India. It is in line with Majeed, Jiang [45], Henri, Luc [47], Khan, Khan [76]. Besides, unidirectional causality reveals running from FDI to financial development [FDI $\rightarrow$ FD] in Pakistan and Srilanka. 
Table 6. Linear causality test following Toda-Yama moto

\begin{tabular}{|c|c|c|c|c|c|}
\hline Dependent & FD & $\mathbf{R}$ & GCF & FDI & Remarks \\
\hline \multicolumn{6}{|c|}{ Panel-A: for Bangladesh } \\
\hline FD & & $9.886^{* * *}$ & $5.205^{*}$ & $5.718^{*}$ & \multirow{4}{*}{$\begin{array}{c}\mathrm{FD} \leftarrow \rightarrow \mathrm{R} ; \mathrm{GCF} \leftarrow \rightarrow \mathrm{FD} ; \mathrm{FDI} \leftarrow \rightarrow \mathrm{FD} \\
\mathrm{FDI} \rightarrow \mathrm{GCF}\end{array}$} \\
\hline $\mathrm{R}$ & $12.650^{* * *}$ & & 0.406 & 1.035 & \\
\hline GCF & $10.003^{* * *}$ & 0.523 & & $5.761 *$ & \\
\hline \multirow{2}{*}{\multicolumn{6}{|c|}{$\begin{array}{l}0.817 \\
\text { Panel -B: for India }\end{array}$}} \\
\hline & & & & & \\
\hline FD & & $5.734 * *$ & $6.323 * * *$ & $10.473^{* * *}$ & \multirow{4}{*}{$\begin{array}{c}\mathrm{FD} \leftarrow \rightarrow \mathrm{R} ; \mathrm{GCF} \leftarrow \rightarrow \mathrm{FD} ; \mathrm{FDI} \leftarrow \rightarrow \mathrm{FD} \\
\mathrm{FDI} \rightarrow \mathrm{GCF}\end{array}$} \\
\hline $\mathrm{R}$ & $10.725^{* * *}$ & & 2.516 & 0.115 & \\
\hline GCF & $5.966^{* * *}$ & 2.924 & & $6.752 * *$ & \\
\hline FDI & $5.302 * * *$ & 3.198 & 0.064 & & \\
\hline \multicolumn{6}{|c|}{ Panel -C: for Pakistan } \\
\hline FD & & $9.648 * * *$ & $6.207 * * *$ & $13.509^{* * *}$ & \multirow{4}{*}{$\begin{aligned} & \mathrm{FD} \leftarrow \rightarrow \mathrm{R} ; \mathrm{GCF} \rightarrow \mathrm{FD} ; \mathrm{FDI} \rightarrow \mathrm{FD} ; \mathrm{FDI} \leftarrow \mathrm{GCF}, \\
& \mathrm{R} \rightarrow \mathrm{FDI}\end{aligned}$} \\
\hline $\mathrm{R}$ & $3.111 *$ & & 2.272 & $10.612 * * *$ & \\
\hline GCF & 0.984 & 2.356 & & 0.175 & \\
\hline FDI & 0.079 & $6.92 * * *$ & $12.458^{* * *}$ & & \\
\hline \multicolumn{6}{|c|}{ Panel -D: for Srilanka } \\
\hline FD & & $3.543 *$ & $4.685^{*}$ & $8.317 * * *$ & \multirow{4}{*}{$\begin{array}{l}\mathrm{FD} \leftarrow \rightarrow \mathrm{R} ; \mathrm{GCF} \leftarrow \rightarrow \mathrm{FD} ; \mathrm{FDI} \rightarrow \mathrm{FD} \\
\mathrm{FDI} \rightarrow \mathrm{GCF} ; \mathrm{R} \rightarrow \mathrm{GCF} ; \mathrm{FDI} \rightarrow \mathrm{GCF}\end{array}$} \\
\hline $\mathrm{R}$ & $3.734 *$ & & 4.894 & $11.122 * * *$ & \\
\hline GCF & $7.921 * * *$ & $8.433 * * *$ & & $10.719 * * *$ & \\
\hline FDI & 2.204 & 1.991 & 0.548 & & \\
\hline
\end{tabular}

Note: the superscript of $* * * * * * / *$ denotes the level of significant at a $1 \% / 5 \% / 10 \%$, respectively

\section{Findings and Conclusions}

Remittances as an alternative source of money supply have played an essential role in several macro dynamic developments over the past decades. However, the impact of remittances immensely differs from the macroeconomic fundamentals of a precipitant economy. As a developing nation, Bangladesh has been experiencing the impact of remittances in the economy, and the role of remittances is still under investigation. The motivation of the study is to investigate the impact of remittances on financial development through the channel of capital formation for the period from 1978-2018. The study applies both symmetry and asymmetry shocks in remittances on financial development by implementing ARDL familiarized by Pesaran, Shin [63] and Nonlinear ARDL introduced by Shin, Yu [9]. Furthermore, the empirical model's directional causalities have been investigated by implementing a non-granger causality test following Toda and Yamamoto [64]. The key finding of the study states below:

First, the preliminary assessment study performed the stationary following ADF test [65], DF-GLS test, PP test [77], and KPSS [68]test. The study also implements a structural break unit root test following Zivot and Andrews [69]. The unit root test results reveal that all the variables are stationary after the first difference, which is essential for implementing the ARDL bound testing approach. The study implements the combined cointegration test following Bayer and Hanck [6]. The F-stats for cointegration test reveals that it is statistically significant at a $1 \%$ level, indicating the existence of a long-run association between remittances, gross capital formation, FDI, and financial development in all sample country estimation.

Second Study findings reveal that remittance inflows are positively statistically significant, associating with the proxy measure of financial development in the long and short run. It is supported by existing literature, as seen in Bolarinwa and Akinbobola [78]; Azizi [71] [79]. Remittance inflows tend to boost demand for financial services and consequently financial sector development. Moreover, remittances encourage recipients to demand and gain access to financial products and services they would not otherwise have [56, 80]. Recent studies show that households who receive migrant remittances have greater access to healthcare services, have better educational opportunities, and have lower poverty levels [81, 82]. Additionally, outside money movement may help create savings possibilities, increase deposits, and promote financial inclusion [83-85].

According to Gross capital formation impact on financial development, study documents positive statistically significant association between them. However, the coefficient magnitude intensity is higher in the long run than in the short-run assessment. These 
findings are applicable to the sample countries in line with Ibrahim and Sare [86], and Bekhet, Yasmin [74].

Next, the nexus between foreign direct investment and financial development study discloses a positive statistically significant connection in the long and short run. Nonetheless, the long-run coefficient produces a higher intensity than the short-run in all countries concerned (see Table 5). These findings are aligned with instances [40-47]. According to Hermes and Lensink [87], the degree of development of the host country's financial system is a critical prerequisite for FDI to benefit. A well-developed and functional financial system increase resource allocation efficiency and a country's absorptive FDI inflows. Omran and Bolbol [88] advocate that the beneficial impact of FDI on growth depends on absorptive capabilities, one of the most significant of which is financial development.

Third, Asymmetric model estimation documents asymmetric association both in the long-run and short-run. The standard Wald test reveals that the test statistics are statistically significant at a1\% level. With the asymmetric effects of remittances, positive and negative shocks expose positive, statistically significant at a $1 \%$ level both in the long-run and short-run. However, in coefficient elasticities, harmful innovations are more critical to financial development than positive innovations in remittances. It suggests that policymakers have to make efforts to formulate policies that induce the migrants to send remittances to the economy. Finally, the directional causality test results disclosed unidirectional causality running from remittances to financial development; it is aligned with Coulibaly [89]; Olayungbo and Quadri [90].

\section{Declarations}

Supplementary Materials: Not applicable

Author Contributions: not applicable

Funding: This research has funded by Institute of Advanced Researched (IAR)-Research Grant, United international University: IAR/2021/PUB/004

Data Availability Statement: all the research data are publically available at World development indicator and International financial statistics

Acknowledgments: not applicable

Conflicts of Interest: The authors declare no conflict of interest.

\section{REFERENCES}

[1] Huang, Y., What determines financial development? 2005.

[2] Voghouei, H., M. Azali, and S.H. Law, Does the political institution matter for financial development? Economic Papers: A journal of applied economics and policy, 2011. 30(1): p. 77-98.
[3] Beck, T., R. Levine, and A. Demirgüç-Kunt, Law and finance: why does legal origin matter? 2002: The World Bank.

[4] Muneeb, M.A., et al., The Role of Remittances in Financial Development: Evidence from Nonlinear ARDL and Asymmetric Causality. The Journal of Asian Finance, Economics and Business, 2021. 8(3): p. 139-154.

[5] Jijin, P., A.K. Mishra, and M. Nithin, Macroeconomic determinants of remittances to India. Economic Change and Restructuring, 2021.

[6] Bayer, C. and C. Hanck, Combining non-cointegration tests. Journal of Time Series Analysis, 2013. 34(1): p. 83-95.

[7] Pesaran, M.H., Y. Shin, and R.J. Smith, Bounds testing approaches to the analysis of level relationships. Journal of Applied Econometrics, 2001. 16(3): p. 289-326.

[8] Banerjee, A., et al., Co-integration, error correction, and the econometric analysis of non-stationary data. OUP Catalogue, 1993.

[9] Shin, Y., B. Yu, and M. Greenwood-Nimmo, Modelling asymmetric cointegration and dynamic multipliers in a nonlinear ARDL framework, in Festschrift in Honor of Peter Schmidt. 2014, Springer. p. 281-314.

[10] Motelle, S.I., From Bank Credit to Economic Growth in Lesotho: A Punctuated Process+. 2008.

[11] Vaaler, P.M., Diaspora Concentration and the Venture Investment Impact of Remittances. Journal of International Management, 2013. 19(1): p. 26-46.

[12] Calderón, C. and L. Liu, The direction of causality between financial development and economic growth. Journal of development economics, 2003. 72(1): p. 321-334.

[13] Demirguc-Kunt, A.R. and M.M. Peria, Do Remittances Promote Financial Development? Journal of Development Economics, 2010. 96: p. 255-264.

[14] Shen, I.-L., F. Docquier, and H. Rapoport, Remittances and inequality: a dynamic migration model. The Journal of economic inequality, 2010. 8(2): p. 197-220.

[15] Liu, J. and M. Qamruzzaman, An asymmetric Investigation of Remittance, Trade Openness Impact on Inequality: Evidence from Selected South Asian Countries. Frontiers in Psychology, 2021: p. 4022.

[16] Miao, M. and M. Qamruzzaman, Dose Remittances Matter for Openness and Financial Stability: Evidence From Least Developed Economies. Frontiers in psychology, 2021. 12.

[17] Giuliano, P. and M. Ruiz-Arranz, Remittances, financial development, and growth. Journal of Development Economics, 2009. 90(1): p. 144-152.

[18] Abdih, Y., et al., Remittances and institutions: Are remittances a curse? World Development, 2012. 40(4): p. 657-666.

[19] Mundaca, B.G., Remittances, financial market development, and economic growth: the case of Latin America and the Caribbean. Review of development economics, 2009. 13(2): p. 288-303.

[20] Ringel, M., et al., Towards a green economy in Germany? 
The role of energy efficiency policies. Applied Energy, 2016. 179: p. 1293-1303.

[21] Shanthi, S., et al., Do diaspora remittances affect banking sector development in Sub Saharan Africa? International Journal of Commerce and Management, 2015.

[22] Aggarwal, R., A. Demirguc-Kunt, and M.S. Martinez Peria, Do workers' remittances promote financial development? 2006: The World Bank.

[23] Greenwood, J. and B. Jovanovic, Financial Development, Growth, and the Distribution of Income. Journal of Political Economy, 1990. 98(5): p. 1076-1107.

[24] Dupas, P. and J. Robinson, Savings Constraints and Microenterprise Development: Evidence from a Field Experiment in Kenya. American Economic Journal: Applied Economics, 2013. 5(1): p. 163-92.

[25] Raza, S.A., et al., Is stock market sensitive to foreign capital inflows and economic growth? Journal of Chinese Economic and Foreign Trade Studies, 2015.

[26] El-Nader, H.M. and A.D. Alraimony, The macroeconomic determinants of stock market development in Jordan. International Journal of Economics and Finance, 2013. 5(6): p. 91-103.

[27] Billmeier, M.A. and I. Massa, What Drives Stock Market Development in the Middle East and Central Asia: Institutions, Remittances, Or Natural Resources? 2007: International Monetary Fund.

[28] Ngare, E., E.M. Nyamongo, and R.N. Misati, Stock market development and economic growth in Africa. Journal of Economics and Business, 2014. 74: p. 24-39.

[29] Aggarwal, R., A. Demirgüç-Kunt, and M.S.M. Pería, Do remittances promote financial development? Journal of development economics, 2011. 96(2): p. 255-264.

[30] Yiheyis, Z. and K. Woldemariam, The effect of remittances on domestic capital formation in select African countries: A comparative empirical analysis. Journal of International Development, 2016. 28(2): p. 243-265.

[31] Omanukwue, P.N., Are immigrants remittance flows a source of capital for development?: a review. Economic and Financial Review, 2006. 44(2): p. 5.

[32] Bjuggren, P., J. Dzansi, and G. Shukur, Remittances and investment. Centre for Excellence for Science and Innovation Studies (CESIS). 2010, Working Paper.

[33] Ratha, D., Workers' remittances: an important and stable source of external development finance. Remittances: development impact and future prospects, 2005: p. 19-51.

[34] Basnet, H.C., et al., Workers' remittances and financial development: the case of South Asia. International Review of Economics, 2021. 68(2): p. 185-207.

[35] Bjuggren, P.-O. and J. Dzansi. Remittances and investment. in 55th Annual Meetings of the North American Regional Science Association International, New York, November, 2008. 2008.

[36] Khan, Z.S. and S. Islam, The effects of remittances on inflation: evidence from Bangladesh. Journal of Economics and Business Research, 2013. 19(2): p. 198-208.
[37] 37. Lartey, E.K.K., Remittances, investment and growth in sub-Saharan Africa. The Journal of International Trade \& Economic Development, 2013. 22(7): p. 1038-1058.

[38] Sultonov, M., The causality relationship between remittances and the real effective exchange rate: the case of the Kyrgyz Republic. International Journal of Economic Policy Studies, 2020. 14(1): p. 167-177.

[39] Bracking, S., Sending money home: are remittances always beneficial to those who stay behind? Journal of International Development, 2003. 15(5): p. 633-644.

[40] Alfaro, L., S. Kalemli-Ozcan, and S. Sayek, FDI, Productivity and Financial Development. The World Economy, 2009. 32(1): p. 111-135.

[41] Fauzel, S., Modeling the relationship between FDI and financial development in small island economies: A PVAR approach. Theoretical Economics Letters, 2016. 6(3): p. 367-375.

[42] Qamruzzaman, M. and J. Wei, Do financial inclusion, stock market development attract foreign capital flows in developing economy: a panel data investigation. Quantitative Finance and Economics, 2019. 3(1): p. 88-108.

[43] Bayar, Y. and M.D. Gavriletea, Foreign Direct Investment Inflows and Financial Development in Central and Eastern European Union Countries: A Panel Cointegration and Causality. International Journal of Financial Studies, 2018. 6(2): p. 55.

[44] Keho, Y., Linkages between Foreign Direct Investment and Financial Development: Evidence from West African Countries. Journal of Applied Finance and Banking, 2020. 10(6): p. $57-75$

[45] Majeed, A., et al., The Impact of Foreign Direct Investment on Financial Development: New Evidence from Panel Cointegration and Causality Analysis. J. Compet, 2021. 13: p. $95-112$

[46] Iamsiraroj, S., The foreign direct investment-economic growth nexus. International Review of Economics \& Finance, 2016. 42: p. 116-133.

[47] Henri, N., N.N. Luc, and N. Larissa, The Long-run and Short-run Effects of Foreign Direct Investment on Financial Development in African Countries. African Development Review, 2019. 31(2): p. 216-229.

[48] Alfaro, L., et al., Does foreign direct investment promote growth? Exploring the role of financial markets on linkages. Journal of Development Economics, 2010. 91(2): p. 242-256.

[49] Henry, P.B., Do stock market liberalizations cause investment booms? Journal of Financial Economics, 2000. 58(1): p. 301-334.

[50] Asamoah, M.E. and I.P. Alagidede, Foreign direct investment, real sector growth and financial development. International Journal of Finance \& Economics, 2021. $\mathbf{n} / \mathbf{a}(\mathrm{n} / \mathrm{a})$

[51] Soumaré, I. and F. Tchana Tchana, Causality between FDI and Financial Market Development: Evidence from Emerging Markets. The World Bank Economic Review, 2015. 29(suppl_1): p. S205-S216. 
[52] Kholdy, S. and A. Sohrabian, Foreign direct investment, financial markets, and political corruption. Journal of Economic Studies, 2008. 35(6): p. 486-500.

[53] Svaleryd, H. and J. Vlachos, Financial markets, the pattern of industrial specialization and comparative advantage: Evidence from OECD countries. European Economic Review, 2005. 49(1): p. 113-144.

[54] Abidin, I.S.Z., et al., Foreign direct investment, financial Development, international trade and energy consumption: Panel data evidence from selected ASEAN Countries. International Journal of Energy Economics and Policy, 2015. 5(3).

[55] Levine, R., Financial development and economic growth: views and agenda. 1999: The World Bank.

[56] Orozco, M. and R. Fedewa, Leveraging efforts on remittances and financial intermediation (Working Paper $I T D=$ Documento de Trabajo ITD; n. 24). 2006: BID-INTAL.

[57] Rao, B.B. and G.M. Hassan, A panel data analysis of the growth effects of remittances. Economic modelling, 2011. 28(1-2): p. 701-709.

[58] Ayadi, R., et al., Determinants of financial development across the Mediterranean, in Economic and Social Development of the Southern and Eastern Mediterranean Countries. 2015, Springer. p. 159-181.

[59] Gadanecz, B. and K. Jayaram, Measures of financial stability-a review. Irving Fisher Committee Bulletin, 2008. 31(1): p. 365-383.

[60] Ramirez, M.D. and H. Sharma, Remittances and growth in Latin America: a panel unit root and panel cointegration analysis. 2008.

[61] Ayyagari, M., T. Beck, and A. Demirgüç-KunT, Small and Medium Enterprises across the Globe: A New Database. 2011, World Bank Publication USA. p. 12-24.

[62] Narayan, P.K., Reformulating Critical Values for the Bounds F-statistics Approach to Cointegration: An Application to the Tourism Demand Model for Fiji. 2004, Monash University: Australia. p. 1-40.

[63] Pesaran, M.H., Y. Shin, and J.R. Smith, Bounds Testing Approaches to the Analysis of Level Relationships. Journal of Applied Econometric 2001. 16: p. 289-326.

[64] Toda, H.Y. and T. Yamamoto, Statistical inference in vector autoregressions with possibly integrated processes. Journal of econometrics, 1995. 66(1-2): p. 225-250.

[65] Dickey, D.A. and W.A. Fuller, Distribution of the Estimators for Autoregressive Time Series with a Unit Root. Journal of the American Statistical Association, 1979. 74(366a): p. 427-431.

[66] Elliott, G., T.J. Rothenberg, and J. Stock, Efficient Tests for an Autoregressive Unit Root. Econometrica, 1996. 64(4): p. 813-36.

[67] Phillips, P.C. and P. Perron, Testing for a unit root in time series regression. Biometrika, 1988. 75(2): p. 335-346.

[68] Kwiatkowski, D., et al., Testing the null hypothesis of stationarity against the alternative of a unit root: How sure are we that economic time series have a unit root? Journal of econometrics, 1992. 54(1-3): p. 159-178.

[69] Zivot, E. and D.W.K. Andrews, Further evidence on the great crash, the oil-price shock, and the unit-root hypothesis. Journal of business \& economic statistics, 2002. 20(1): p. 25-44.

[70] Bettin, G. and A. Zazzaro, Remittances and financial development: substitutes or complements in economic growth? Bulletin of Economic Research, 2012. 64(4): p. 509-536.

[71] Azizi, S., Impacts of remittances on financial development. Journal of Economic Studies, 2020.

[72] MEHTA, A.M., et al., The role of remittances in financial development: Evidence from nonlinear ARDL and asymmetric causality. The Journal of Asian Finance, Economics and Business, 2021. 8(3): p. 139-154.

[73] Qamruzzaman, M. and W. Jianguo, NEXUS BETWEEN REMITTANCE AND HOUSEHOLD CONSUMPTION: FRESH EVIDENCE FROM SYMMETRIC OR ASYMMETRIC INVESTIGATION. Journal of Economic Development, 2020. 45(3).

[74] Bekhet, H.A., T. Yasmin, and R.W. Al-Smadi, Dynamic linkages among financial development, economic growth, energy consumption, $\mathrm{CO} 2$ emissions and gross fixed capital formation patterns in Malaysia. International Journal of Business and Globalisation, 2017. 18(4): p. 493-523.

[75] Guiso, L., P. Sapienza, and L. Zingales, The role of social capital in financial development. American economic review, 2004. 94(3): p. 526-556.

[76] Khan, H., U. Khan, and M.A. Khan, Causal Nexus between Economic Complexity and FDI: Empirical Evidence from Time Series Analysis. The Chinese Economy, 2020. 53(5): p. 374-394.

[77] Phillips, P.C.B. and P. Perron, Testing for a unit root in time series regression. Biometrika, 1988. 75(2): p. 335-346.

[78] Bolarinwa, S. and T.O. Akinbobola, Remittances-financial development nexus: Causal evidence from four African countries. Ilorin Journal of Economic Policy, 2021. 8(1): p. $1-17$.

[79] Cao, S. and S.J. Kang, Personal Remittances and Financial Development for Economic Growth in Economic Transition Countries. International Economic Journal, 2020. 34(3): p. 472-492.

[80] Olowa, O.W. and A.M. Shittu, Remittances and income inequality in rural Nigeria. journal of Business Management and Economics, 2012. 3(5): p. 210-221.

[81] Amakom, U. and C.G. Iheoma, Impact of migrant remittances on health and education outcomes in sub-Saharan Africa. IOSR Journal of Humanities and Social Science, 2014. 19(8): p. 33-44.

[82] Frank, R., et al., The Relationship Between Remittances and Health Care Provision in Mexico. American Journal of Public Health, 2009. 99(7): p. 1227-1231.

[83] Al-Tarawneh, A., The role of workers' remittances in development of Jordanian banking sector. International Journal of Business and Economics Research, 2016. 5(6): p. 
$227-234$

[84] 84. Meyer, D. and A. Shera, The impact of remittances on economic growth: An econometric model. EconomiA, 2017. 18(2): p. 147-155.

[85] Shera, A. and D. Meyer, Remittances and their impact on Economic Growth. Periodica Polytechnica Social and Management Sciences, 2013. 21(1): p. 3-19.

[86] Ibrahim, M. and Y.A. Sare, Determinants of financial development in Africa: How robust is the interactive effect of trade openness and human capital? Economic Analysis and Policy, 2018. 60: p. 18-26.

[87] Hermes, N. and R. Lensink, Foreign direct investment, financial development and economic growth. Journal of Development Studies, 2003. 40(1): p. 142-163.

[88] Omran, M. and A. Bolbol, Foreign Direct Investment, Financial Development, and Economic Growth: Evidence from the Arab Countries. Review of Middle East Economics and Finance, 2003. 1(3): p. 37-55.

[89] Coulibaly, D., Remittances and financial development in Sub-Saharan African countries: A system approach. Economic Modelling, 2015. 45: p. 249-258.

[90] Olayungbo, D. and A. Quadri, Remittances, financial development and economic growth in sub-Saharan African countries: evidence from a PMG-ARDL approach. Financial Innovation, 2019. 5(1): p. 1-25. 